\title{
Analyzing Four-Year Public University and Two-Year College Graduation Rates
}

\author{
David R. Ober ${ }^{1}$, John A. Beekman², Rebecca L. Pierce ${ }^{2}$ \\ ${ }^{1}$ Department of Physics and Astronomy, Ball State University, Muncie, IN \\ ${ }^{2}$ Department of Mathematical Sciences, Ball State University, Muncie, IN \\ Correspondence: Rebecca L. Pierce, Department of Mathematical Sciences, Ball State University, Muncie, IN, USA.
}

Received: February 6, 2018

Accepted: March 11, $2018 \quad$ Online Published: March 23, 2018

doi:10.11114/jets.v6i4.3129

URL: https://doi.org/10.11114/jets.v6i4.3129

\begin{abstract}
This paper examines the graduation rates between 2000 and 2015 of United States colleges and universities at the national, state, and institutional levels. This research focuses on two-year and four-year programs. Rates are investigated longitudinally along with variables that distinguish between public/private institutions, percentages of full-time and part-time enrollments, a variety of completion times, and levels of academic achievement at entry that include SAT scores and high school GPAs. The paper uses a logistic growth function that has been used by other researchers to model four-, five-, and six-year graduation rates of individuals and selected cohort groups; graduation rate trajectories for students of differing academic achievement backgrounds are projected into the future to demonstrate maximum graduation rates expected for entering cohorts. Included is the analysis of national, state, and institutional graduation-rate results in four-year institutions of the 50 states; examples from 14 public colleges and universities in Indiana and several surrounding states are also considered. In addition to fitting their graduation rates to the logistic function and extracting associated growth variables, we use percentages of part-time students to predict two- and four-year graduation rates at the national, state, and institutional levels in the 50 states. The analysis examined the graduation rates between 2000 and 2015 of United States colleges and universities and showed no correlation between a state's two-year and four-year cohort graduation rates; verified an inverse mathematical relationship between graduation rates and percentage of part-time students; confirmed that for median SAT scores of 800 or lower one expects very low on-time graduation rates.
\end{abstract}

Keywords: two-year and four-year completion rates, logistic completion-rate predictions, part-time students, first-time full-time retention

\section{Introduction}

With the passage of the Student Right-to-Know and Campus Security Act of 1990, colleges and universities that receive federal funding for student financial aid programs were required to provide completion or graduation rate information. Students and parents also had access to institutional data in such areas as licensure/certification rates and employment. In 1997, the Integrated Postsecondary Education Data System (IPEDS) began collecting these and other appropriate institutional measures for annual cohorts of first-time full-time students seeking certificates, and two-year and four-year degrees; also included were percentages of students completing programs and degrees in 150 percent of normal times. With passage of the Higher Education Opportunity Act of 2008, institutions began reporting graduation rates for 200 percent of normal times, or 4 years and 8 years for associate and bachelor's degrees, respectively.

In the period 1990-2015, millions of students have been studying at public universities and community colleges. It is of interest to the students and their families, as well as to the states and communities that provide such education, to study the graduation rates of the students. Such research must separate programs (certificates, two-years, and four-years) and may investigate measures that include academic achievement and aptitude at entry, enrollment intensity (full-time versus part-time students), lengths of time to complete programs (such as 100, 150, and 200 percent of normal time), and family variables of the students (socioeconomic status and ethnicity). 


\subsection{Research Questions}

This analysis investigates several research questions and topics that pertain to all 50 states, using cohort data from 2006to 2010 and graduation rates up to and including 2014 available from a variety of resources. Included are the following:

- Is there a correlation between state public two-year and four-year cohort graduation rates?

- Does a relationship between the percentage of part-time students and the first-time full-time cohort graduation rates in two-year and four-year public institutions exist that can be used to determine graduation rates?

- How does the number of full-time first-time public community college two-year cohort degrees compare to its total annual number of certificates and degrees awarded between 2004 and 2014 ?

- What influence do SAT scores have on determining the graduation rates of first-time full-time cohort students in four-year public institutions?

- Use empirical data and a logistic graduation-rate model to predict graduation rate trajectories for two-year and four-year public institutions.

Analyzed are data for 2006 to 2010 obtained from IPEDS, Chronicle of Higher Education College Completion project (2012 and updated 2015), and National Center for Education Statistics (2015). An explanation of the UCLA HERI DeAngelo (2011) formula for graduation rate is given and specific values for several public universities are determined. Also presented are trajectories for two-year and four-year public institutions.

Specifically, a discussion and explanation for the formulas below:

$$
\text { Percent Graduation Rate }=\mathrm{C}_{\max } /\left[1+\left(\exp \left(-\alpha\left(\mathrm{t}-\mathrm{t}_{1 / 2}\right) / \mathrm{C}_{\max }\right)\right]\right.
$$

and

$$
\text { Probability of degree completion }=\text { EXP }[\mathrm{X}] /(1+\mathrm{EXP}[\mathrm{X}])
$$

where $X=\alpha+\beta_{1} x_{1}+\beta_{2} x_{2}+\ldots+\beta_{i} x_{i} \alpha=$ constant, $\beta_{i}=$ coefficient estimated from the logistic regression, and $x_{i}=$ independent variable, whose value can come from an individual student or the mean of a cohort of students.

\section{Data Analysis and Results}

\subsection{State-Level Graduation Rates of Public Two-Year and Four-Year Institutions Show Little to No Correlation}

Figure 1 shows a comparison of 150 percent normal-time graduation rates for 2013 of two-year versus four-year programs for the 50 States. (See Appendix A for the two-year and four-year graduation-rate data, Tables A1 and A2, respectively.) Note, the state with the highest associate-degree program graduation rates (South Dakota) ranked $34^{\text {th }}$ for its bachelor's students graduating in 6 years $(150 \%$ of normal time); similarly, the state with the highest bachelor's-degree program graduation rates (Delaware) ranked $34^{\text {th }}$ for its associate-degree students graduating in 3 -years (150\% of normal time). The state with the lowest associate-degree program graduation rates (Indiana) ranked $26^{\text {th }}$ for its bachelor's degree candidates graduating in 6 years ( $150 \%$ of normal time).

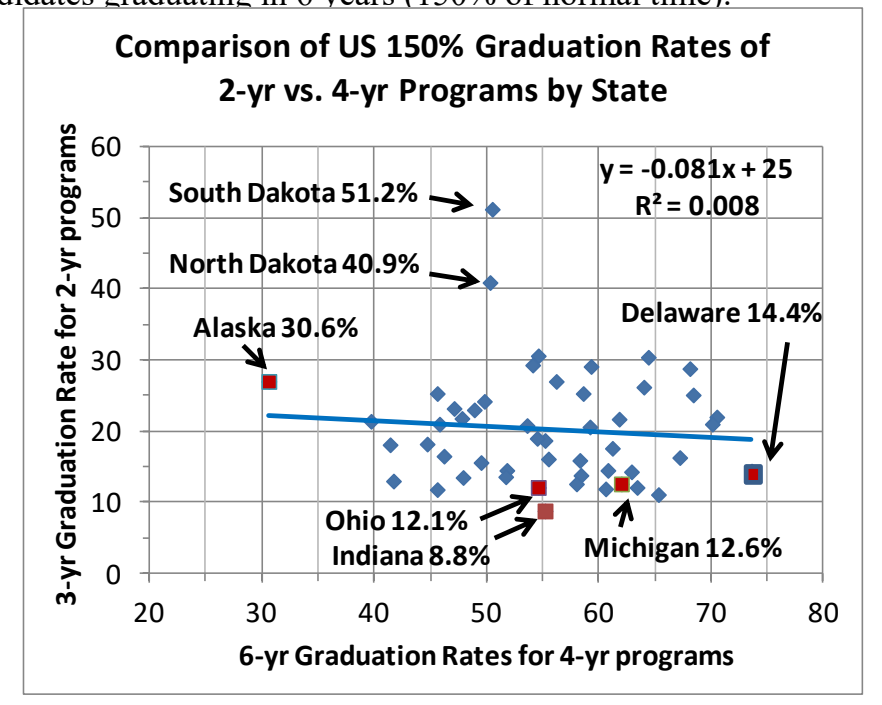

Figure 1. Comparison of US $150 \%$ graduation rates of two-year versus four-year programs by state 
The small negative slope and small $\mathrm{R}^{2}(0.01)$ in Figure 1 suggest that there is no correlation between a state's two-year and four-year public institution graduation rates. Therefore, the data do not support the following: if a state has the best graduation rate in a two-year program, it will also have the best rate in a four-year program; similarly, having a high four-year graduation rate does not correlate with having a high two-year graduation rate.

\subsection{A Model for Predicting Four-Year and Two-Year Graduation Rates From Part-Time Student Percentages}

Do the percentages of part-time students in two-year and four-year public institutions predict graduation rates? To answer this research question, data from the National Center for Education Statistics at the national and state level are considered.

\subsubsection{National-Level Part-Time Percentages Compared for Two-Year and Four-Year Public Institutions}

At the national level, according to the National Center for Education Statistics (2015) for the 2014-15 academic-year, fall enrollments of public two-year institutions had 62.7\% part-time students while public four-year institutions had $23.7 \%$ part-time students. The 2016 first-time full-time data for graduation rates for $150 \%$ of normal time were $29.4 \%$ and $58.5 \%$, respectively, for two-year institutions (2010 starting cohort) and four-year institutions (2008 starting cohort).

Except for those cases where entering freshmen in either two- or four-year programs have large numbers of credit hours from AP or dual-credit courses, or credit by examination, the part-time rates of $62.7 \%$ and $23.7 \%$ would suggest that upper limits to $100 \%$ normal-time graduation rates would be about $37.3 \%$ and $76.3 \%$ for two-year and four-year institutions, respectively. The above national data for $150 \%$ normal graduation rates of $29.4 \%$ and $58.5 \%$, respectively, for two- and four-year instructions are about $80 \%$ of these hypothetical upper limits. Without considering any differences in academic abilities, similar "limiting" scenarios associated with $10 \%$ or $90 \%$ part-time students give rise to limiting upper limits to graduation rates that are less than $90 \%$ and $10 \%$, respectively, for $100 \%$ normal on-time graduation rates. (150\% normal graduation times could be greater than the $100 \%$ normal-time estimates.) For the above assumptions, this logic suggests that a graphical analysis of graduation rates versus percentages of part-time students could give rise to trends that are hyperbolic in nature (percentage of part-time students times graduation rate equals a constant) as shown in Figure 2.

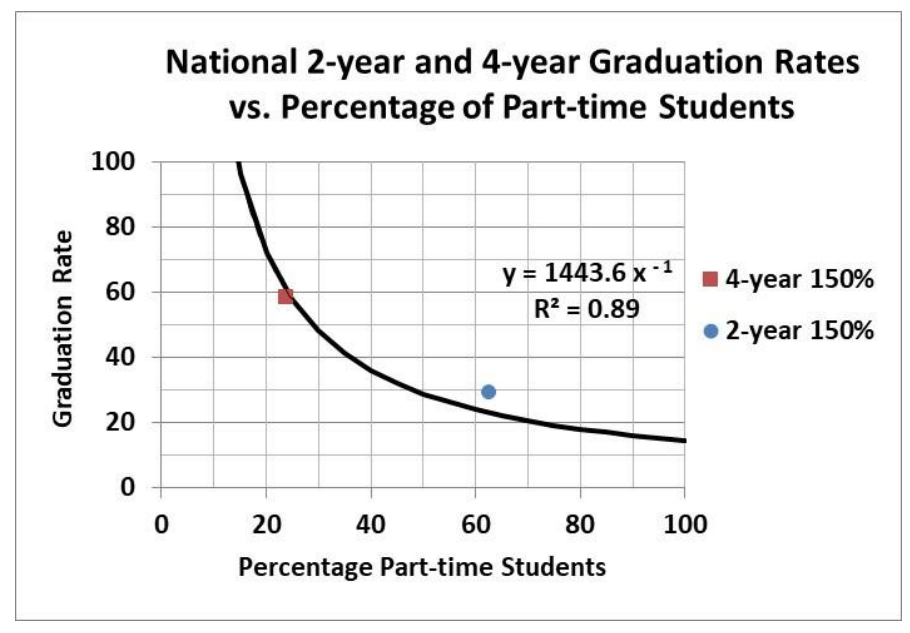

Figure 2. National two-year and four-year graduation rates versus percentage of part-time students

One could argue that fitting only two data points with a one-constant model is not a major accomplishment. However, this mathematical relationship provides insight into a logical explanation as to how community colleges (and bachelor's granting institutions) $100 \%$ and $150 \%$ normal-time graduation rates are affected by their percentages of part-time students. Therefore, percentages of part-time students are worthy of investigation for different groups of aggregation in both two-year and four-year post-secondary institutions.

\subsubsection{State-Level Percentages of Part-Time Students in Two-Year and Four-Year Schools Show Weak Correlation}

Before investigating possible relationships between graduation rates and percentages of part-time students in two-year and four-year state-specific public institutions, the authors analyzed the 50-state data set associated with Figure 1 to determine whether there is a correlation between a state's percentage of part-time students in its two-year and four-year institutions. Figure 3 displays these results.

These results are similar to results presented in Figure1; there is a very small correlation between a state's part-time rates in their two-year and four-year programs. The 50-state part-time percentages were $19.9 \%$ and $59.5 \%$ for the public 
institutions of four-year and two-year degrees, respectively. (The 50-state corresponding 150 percent of normal-time graduation were $57.6 \%$ and $19.4 \%$ for four-year and two-year institutions, respectively.)

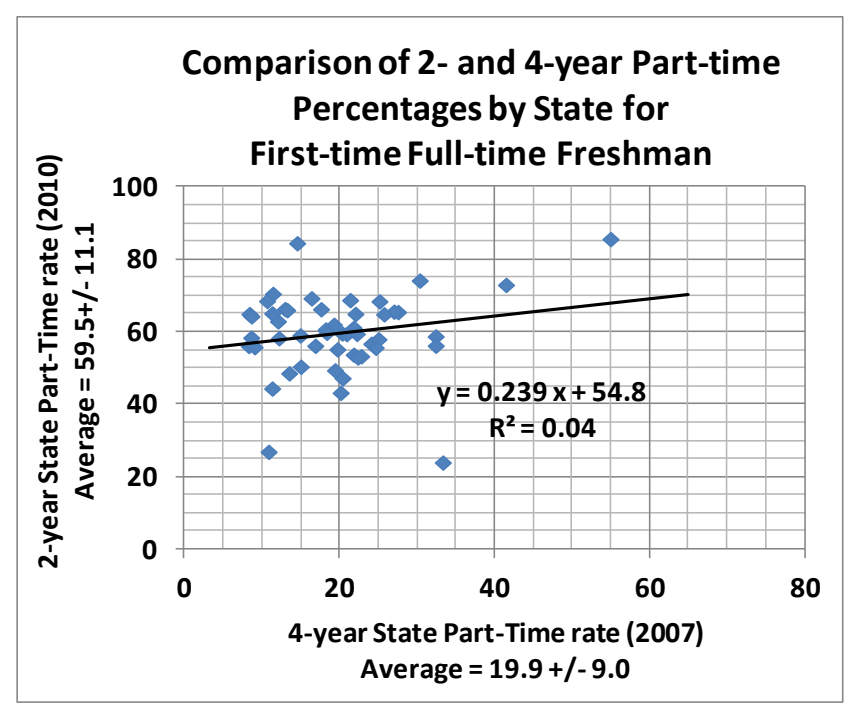

Figure 3. Two-year and four-year part-time percentages by state for first-time full-time freshman

2.2.3 Models for Predicting Institutional-Level Graduation Rates From Their Part-Time Percentages in the 50 States

Observing that South Dakota and North Dakota had the highest 150\% normal-time graduation rates $(51.2 \%$ and $40.9 \%$, respectively) and Indiana had the lowest (8.8\%) for two-year degree programs, it was decided to investigate percentages of part-time students in both two-year and four-year programs at the public institutions for all 50 states.

First, the authors investigated part-time percentage ranges for students in two-year programs for South Dakota, North Dakota, Indiana, and several states surrounding Indiana. South Dakota has five institutions, one with student population less than 20\% part-part-time students and four two-year schools between $20 \%$ and $40 \%$ part-time students. North Dakota has five institutions, one with student population between $20 \%$ and $40 \%$ part-part-time students, three two-year schools between $40 \%$ and $60 \%$ part-time students, and a school with between $60 \%$ and $80 \%$ part-time students. However, Indiana's community college system with 14 regional sites has its percentage of part-time students between $60 \%$ and $80 \%$. This percentage of part-time students is also more than for the three surrounding states of Illinois, Michigan, and Ohio that have 23 of 48,10 of 30, and 8 of 25 institutions, respectively, each with percentages of part-time students less than $60 \%$. Presented in Table B1 of Appendix B are the two-year ranges of the numbers of institutions for each of the 50 states with percentages of the ranges $<20 \%, 20 \%$ to $40 \%, 40 \%$ to $60 \%, 60 \%$ to $80 \%$, and $>80 \%$. Presented in Figure 4 is a comparison of the two-year 150 percent normal-time graduation rates versus the percentage of part-time students for each of the 50 states. The Figure 4 data have been fitted with the one-constant model just introduced and shown in Figure 2.

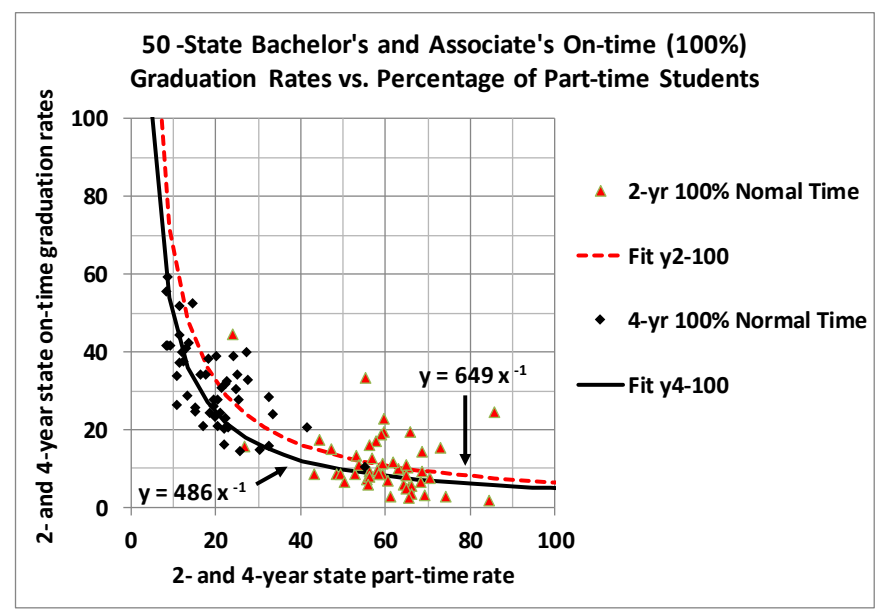

Figure 4. 50-State bachelor's and associate's on-time graduation rates versus percentage of part-time students 
Second, the authors investigate part-time percentage ranges of students in four-year programs for the states of South Dakota, North Dakota, Indiana, and several states surrounding Indiana. In addition, the investigation included three states with the highest 150\% normal-time graduation rates: Delaware, Virginia, and New Hampshire. South Dakota has seven four-year institutions, one with student population less than 20\% part-time students, three schools between $20 \%$ and $40 \%$ part-time students, and three schools between $40 \%$ and $60 \%$ part-time students. North Dakota has seven institutions, two with student populations less than 20\% part-part-time students, four between $20 \%$ and $40 \%$ part-time students, and one four-year school between $40 \%$ and $60 \%$ part-time students. However, Indiana has 14 schools, five with less than $20 \%$ part-time students, one between $20 \%$ and $40 \%$ part-time students, and eight with more than $40 \%$ part-time students. This large percentage of part-time students for four-year schools is more than the three surrounding states of Illinois, Michigan, and Ohio that have 1 of 11,0 of 9 , and 0 of 14 institutions, respectively, with percentages of part-time students greater than 40\%. Presented in Table B2 of Appendix B are the four-year ranges of the numbers of institutions for each of the 50 states with percentages of the ranges $<20 \%, 20 \%$ to $40 \%$, and $>40 \%$. Presented in Figure 5 is a comparison of the four-year $150 \%$ normal-time graduation rates versus the percentage of part-time students for each of the 50 states. The Figure 5 data have been fitted with the one-constant model

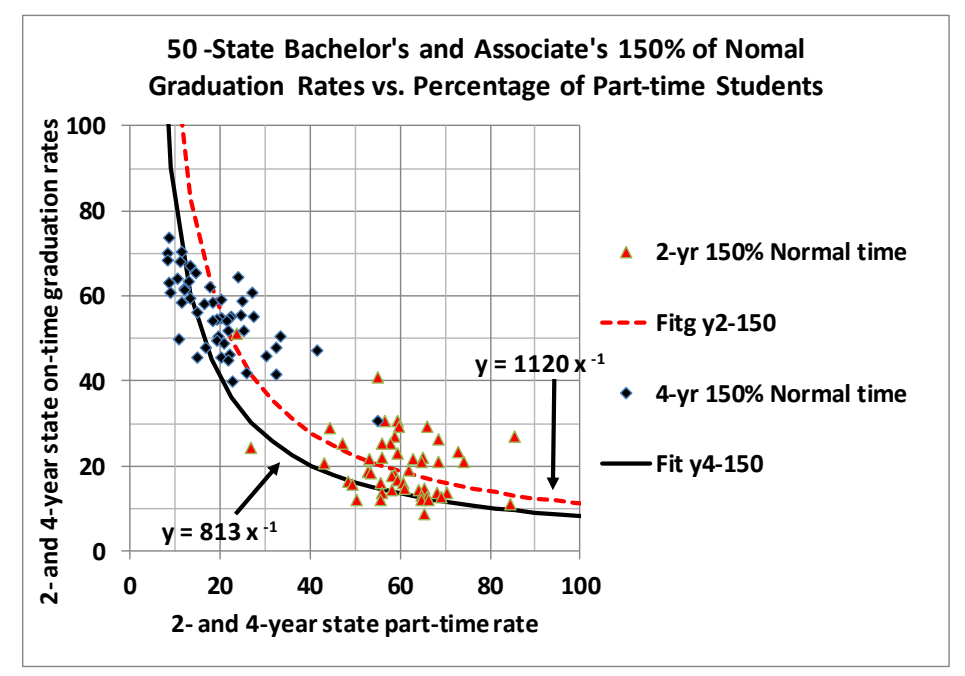

Figure 5. 50-State bachelor's and associate's 150 percent of normal time graduation rates versus percentage of part-time students

Table 1. Summary of Percentage of Part-time Students

\section{Number of Public Schools with}

Total Number of Schools

Percentages of Part-time Students in Ranges

\begin{tabular}{lcccccc} 
& & $<20 \%$ & $20 \%$ to $40 \%$ & $40 \%$ to $60 \%$ & $60 \%$ to $80 \%$ & $>80 \%$ \\
\hline 2-year schools & 919 & 15 & 84 & 393 & 398 & 29 \\
4-year schools & 525 & 314 & 161 & 50 & - & - \\
\hline
\end{tabular}

Table 1 summarizes the percentage ranges of part-time students in two-year and four-year institutions for the 50 states of Tables B1 and B2 in Appendix B. This table delineates large differences in the percentages of part-time students in two-year and four-year schools that lead to a portion of the corresponding disparities in their graduation rates.

\subsubsection{Institutional-Level Data Shows Strong Relationship Between Part-Time Student Percentages and Graduation}

Rates

The state-level graduation rate data, for the 50 states previously noted and analyzed in this study (Chronicle of Higher Education College Completion project, 2012, and updated 2015), was aggregated from over 900 two-year institutions and over 500 four-year institutions. The institution-level percentages of part-time students for $100 \%$ and $150 \%$ on-time graduation rates were then used to study the two-year and four-year data sets using the two-parameter model ( $\mathrm{Y}=\mathrm{A} / \mathrm{X}$ $+\mathrm{B})$ that predicted graduation rates $(\mathrm{Y})$ from the percentages of part-time students $(\mathrm{X})$. 
Table 2. Graduation rate predictions for institutional data sets from percentages of part-time students

\begin{tabular}{lcccc}
\hline \multicolumn{1}{c}{ Public institution types regular and binned data files } & \multicolumn{3}{c}{$\mathrm{Y}=\mathrm{A} / \mathrm{X}+\mathrm{B}$} \\
& Graduation time & $\mathrm{A}$ & $\mathrm{B}$ & $\mathrm{R}^{2}$ \\
\hline 2-year (919 institutions) & $100 \%(2 \mathrm{yr})$ & 41.4 & 11.6 & 0.03 \\
2-year binned (31 bins) & $100 \%(2 \mathrm{yr})$ & 350.6 & 5.8 & 0.64 \\
\hline 2-year (919 institutions) & $150 \%(3 \mathrm{yr})$ & 37.6 & 21.4 & 0.02 \\
2-year binned (31 bins) & $150 \%(3 \mathrm{yr})$ & 280.6 & 16.8 & 0.57 \\
\hline 4-year (525 institutions) & $100 \%(4 \mathrm{yr})$ & 93.4 & 17.8 & 0.37 \\
4-year binned (23 bins) & $100 \%(4 \mathrm{yr})$ & 118.7 & 15.7 & 0.82 \\
\hline 4-year (525 institutions) & $150 \%(6 \mathrm{yr})$ & 112.1 & 38.6 & 0.30 \\
4-year binned (23 bins) & $150 \%$ (6 yr) & 117.9 & 36.9 & 0.71 \\
\hline
\end{tabular}

Results for the predictions of the 919 two-year institutions are shown in Table 2 and Figures $6 \mathrm{a}$ and $6 \mathrm{~b}$ for students graduating in two years and three years, respectively; the two-year rate and three-year rate are referred to as $100 \%$ and $150 \%$ of the normal on-time rates, respectively.

The two-year data consisting of 919 data points possess a wide range of graduation rates at each percentage of part-time students and the model only describes the gross features of the data with $\mathrm{R}^{2}=0.03$ and 0.02 for the $100 \%$ and $150 \%$ data sets, respectively. However, when the model is used to analyze the four-year institutional data set for 525 institutions, the model provided improved descriptions of the $100 \%$ and $150 \%$ data sets with $\mathrm{R}^{2}$ values of 0.37 and 0.30 , respectively. (See Table 2, Figures 7a and 7b)

In order to investigate whether the model which described the graduation rate-percentage of part-time students for the national and state-level data could also be used to describe the institutional-level data sets, data were binned for both the two-year (919 data points) and four-year (525 data points) institutions. The number of bins was the square root of the data-set size by a procedure similar to that described by Coletta and Phillips (2005). Presented in Table 2 and in Figures $6 \mathrm{a}$ and $6 \mathrm{~b}$ and in Figures $7 \mathrm{a}$ and $7 \mathrm{~b}$, are the results of applying the model $(\mathrm{Y}=\mathrm{A} / \mathrm{X}+\mathrm{B})$ to the two-year and four-year institutional data for $100 \%$ and $150 \%$ on-time graduation rates. The model indicated a strong relationship between graduation rate and percentage of part-time students in all four cases with $\mathrm{R}^{2}$ values ranging from 0.57 to 0.82 (see Table 2). Figures $7 \mathrm{a}$ and $7 \mathrm{~b}$ (four-year data for $100 \%$ and $150 \%$ normal on-time graduation rates) show that the binned and entire institutional data sets have predictions that are quite similar over the entire data ranges.

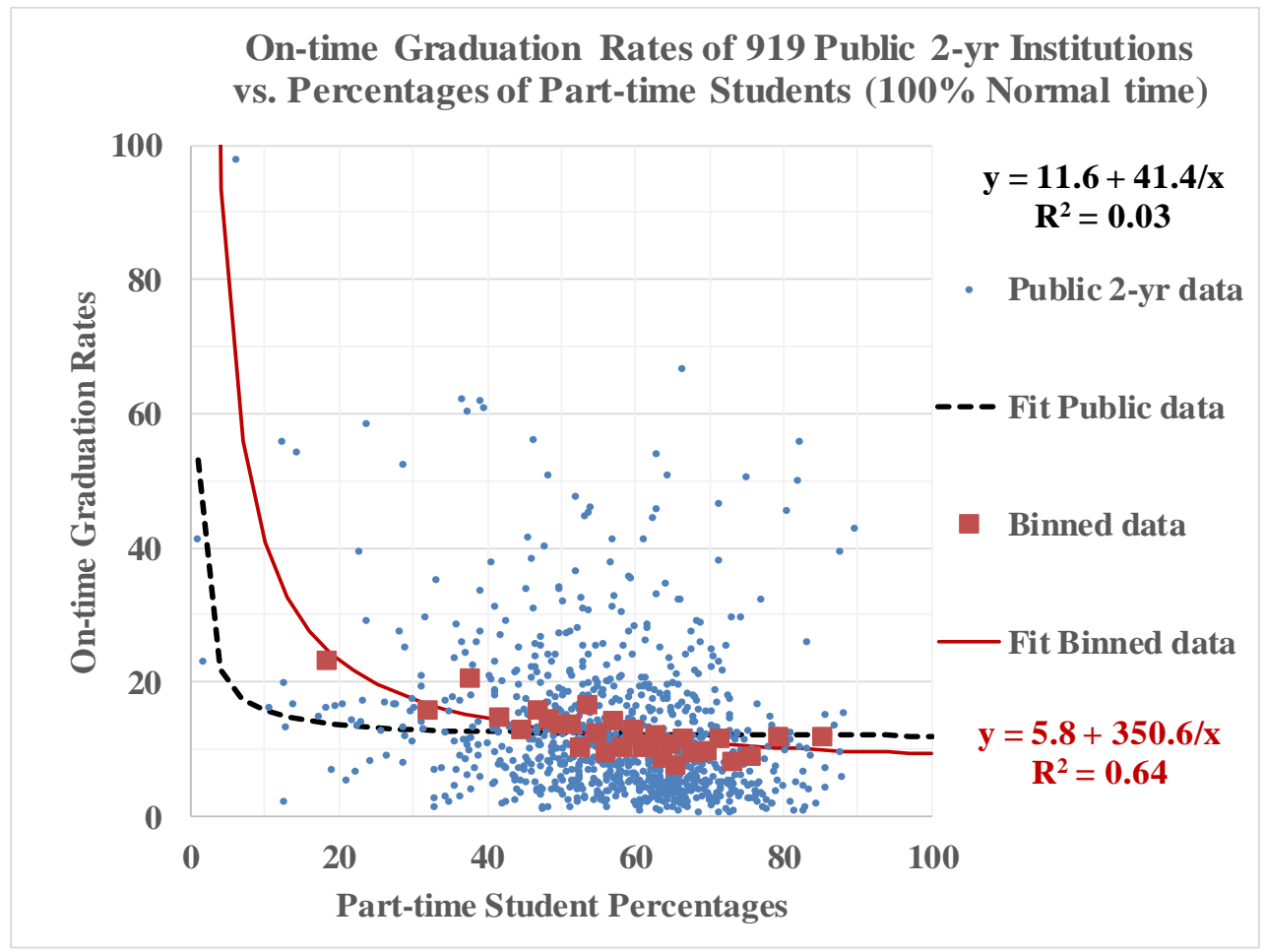

Figure 6a. On-time graduation rates public two-year institutions versus percentage of part-time students (100\% normal time) 


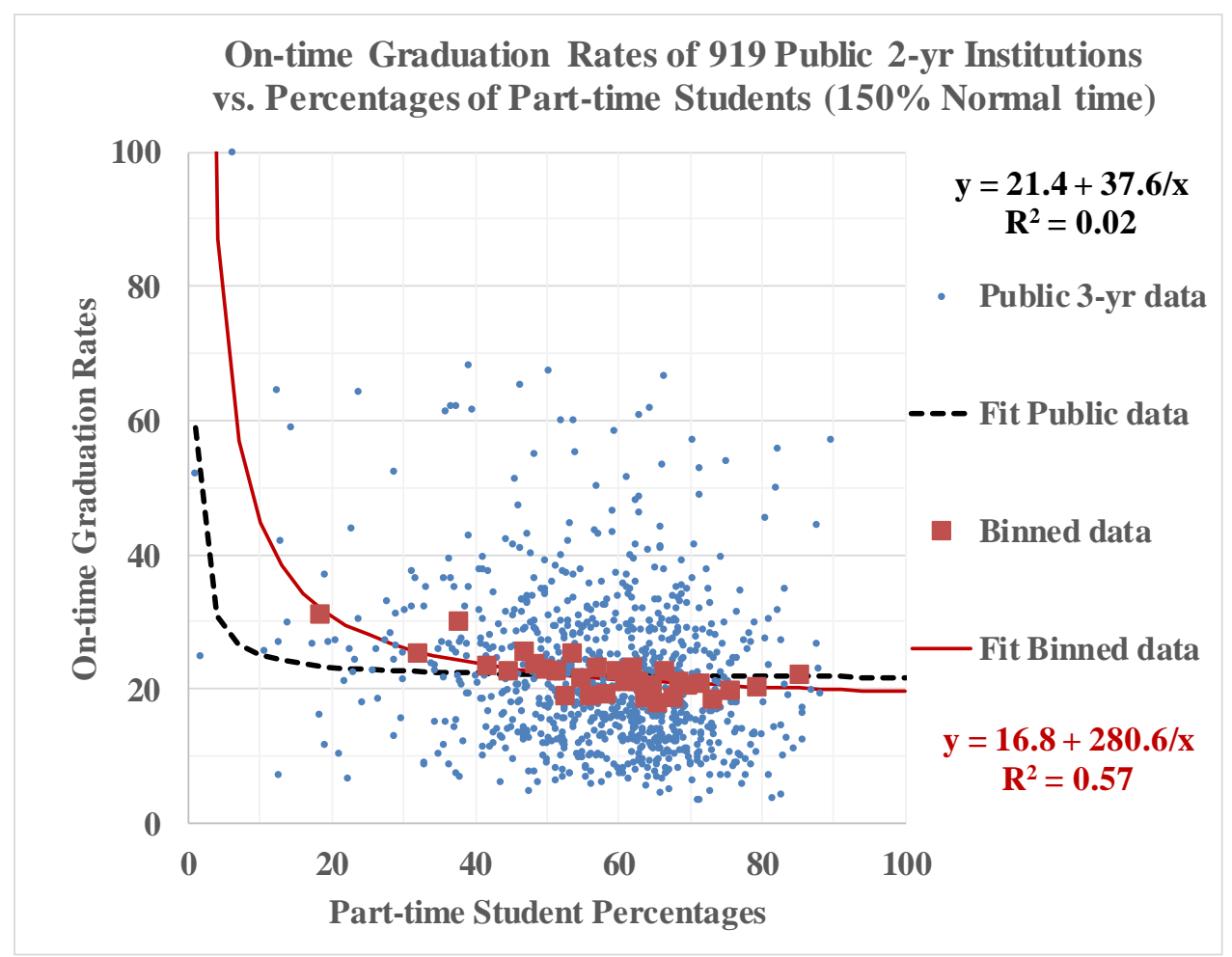

Figure 6b. On-time graduation rates public two-year institutions versus percentage of part-time students (150\% normal time)

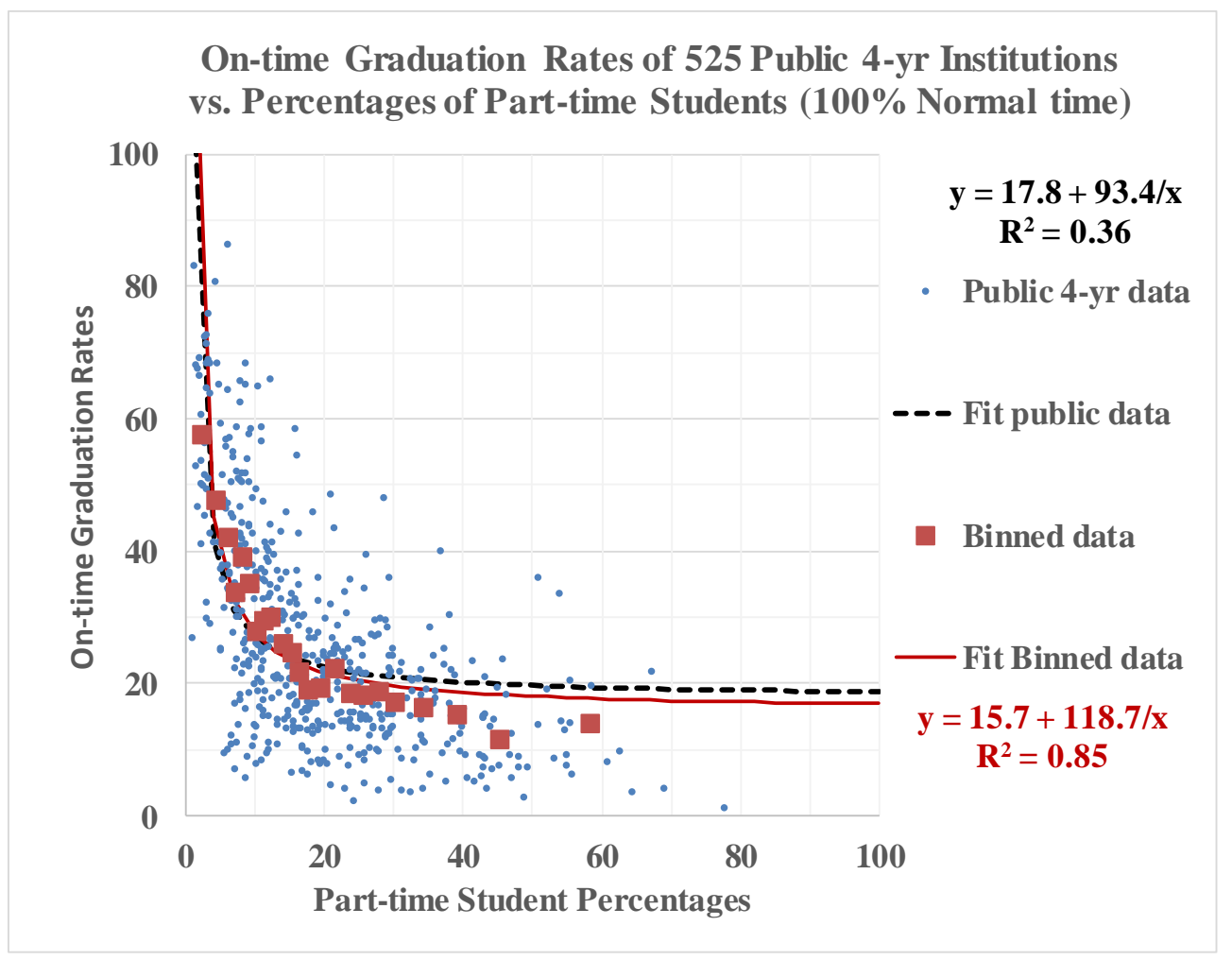

Figure 7a. On-time graduation rates public four-year institutions versus percentage of part-time students (100\% normal time) 


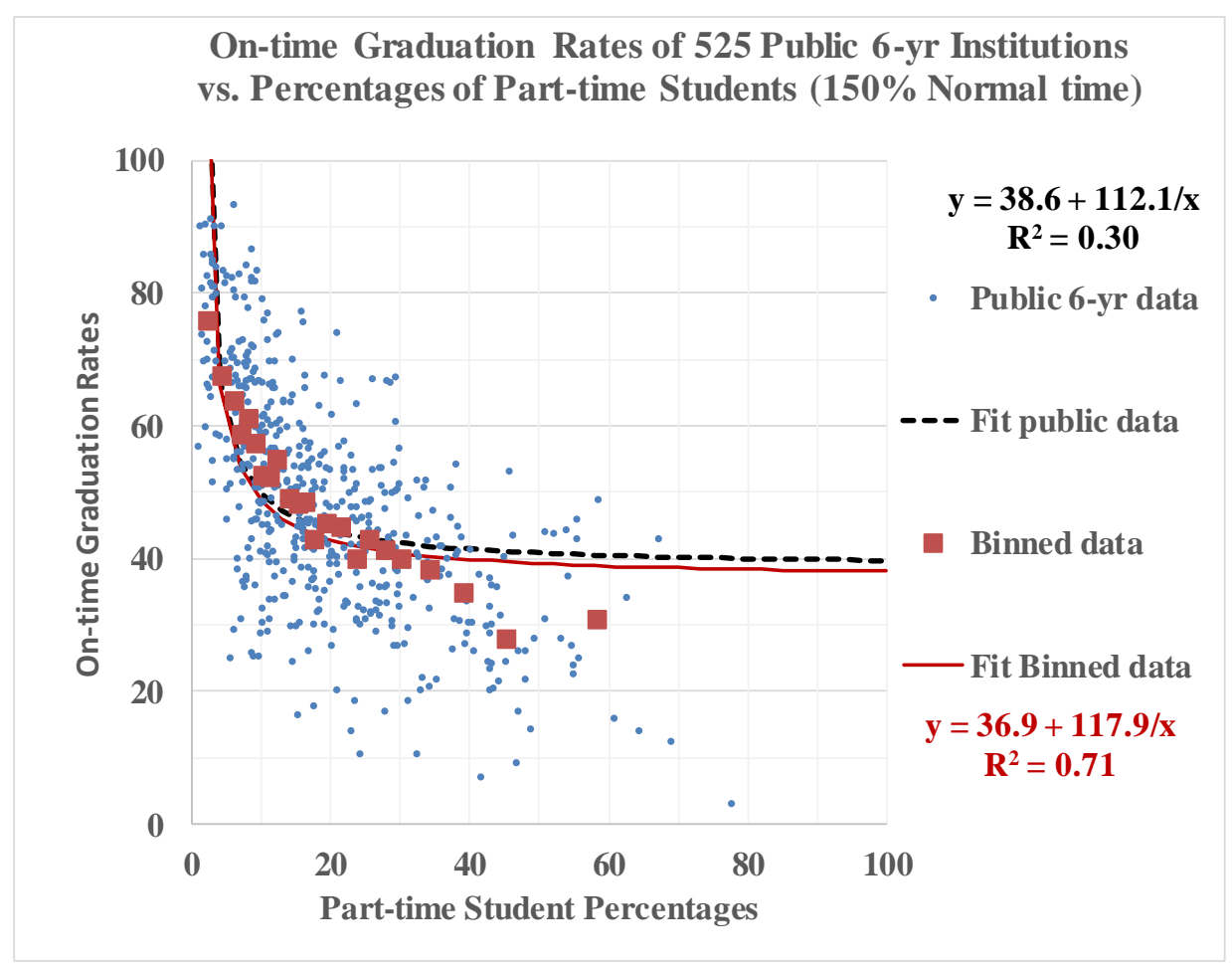

Figure $7 \mathrm{~b}$. On-time graduation rates public four-year institutions versus percentage of part-time students (150\% Normal time)

\subsubsection{Predicting State Graduation Rates From Percentages of Part-Time Students in Four-Year Public Institutions}

For each of the 50 states one-parameter $(\mathrm{Y}=\mathrm{A} / \mathrm{X})$ and two-parameter $(\mathrm{Y}=\mathrm{A} / \mathrm{X}+\mathrm{B})$ models were used to predict the on-time $(100 \%)$ graduation rate $\mathrm{Y}$ in terms of the percentage of part-time students $\mathrm{X}$ for each institution; the 525 institutions previously analyzed represented the 50-state data set (see Table 2). Presented in Figures 8a, 8b, 8c, and 8d are results for California, Illinois, New York, and Indiana, respectively. These four states were chosen from the 50 states analyzed due to their large numbers of institutions (California - 32 and New York -30), and some wider ranges of percentages of part-time students (Illinois - up to approximately $43 \%$ and Indiana - up to approximately 55\%). The New York data with its one-parameter model fit $(\mathrm{Y}=\mathrm{A} / \mathrm{X})$ also illustrates the need (with $\mathrm{R}^{2}<0$ ) to use a model with a constant such as the two-parameter model $(\mathrm{Y}=\mathrm{A} / \mathrm{X}+\mathrm{B})$. Presented in Appendix $\mathrm{C}$ are the results of the analyses for all 50 states.

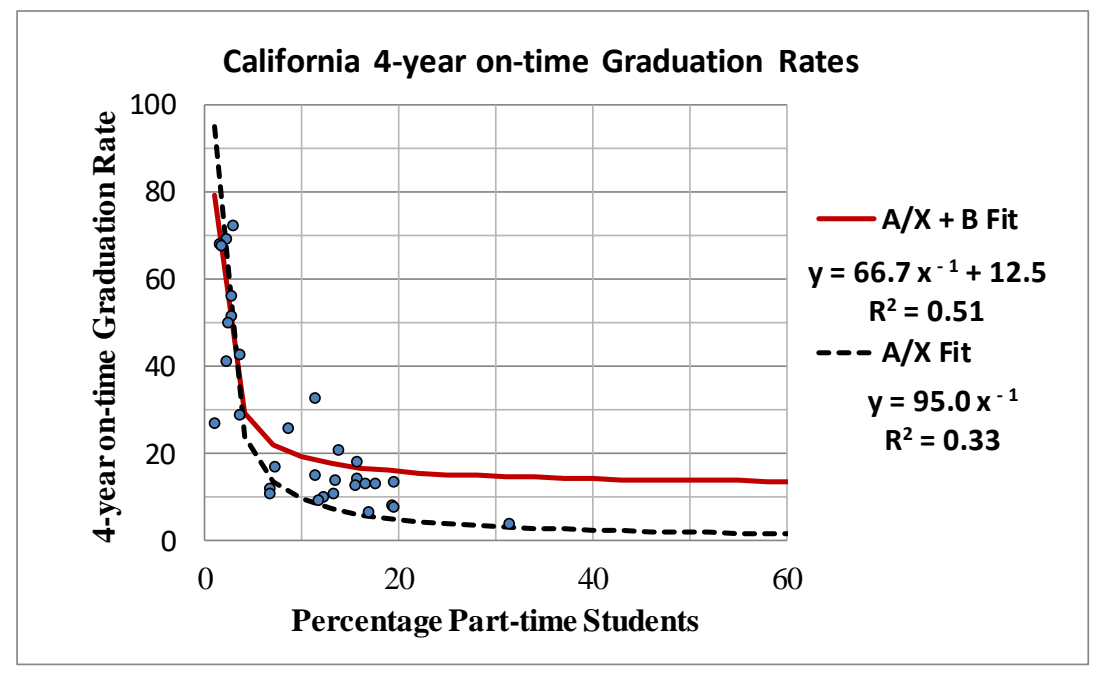

Figure 8a. Predicted on-time graduation rates for four-year California institutions 


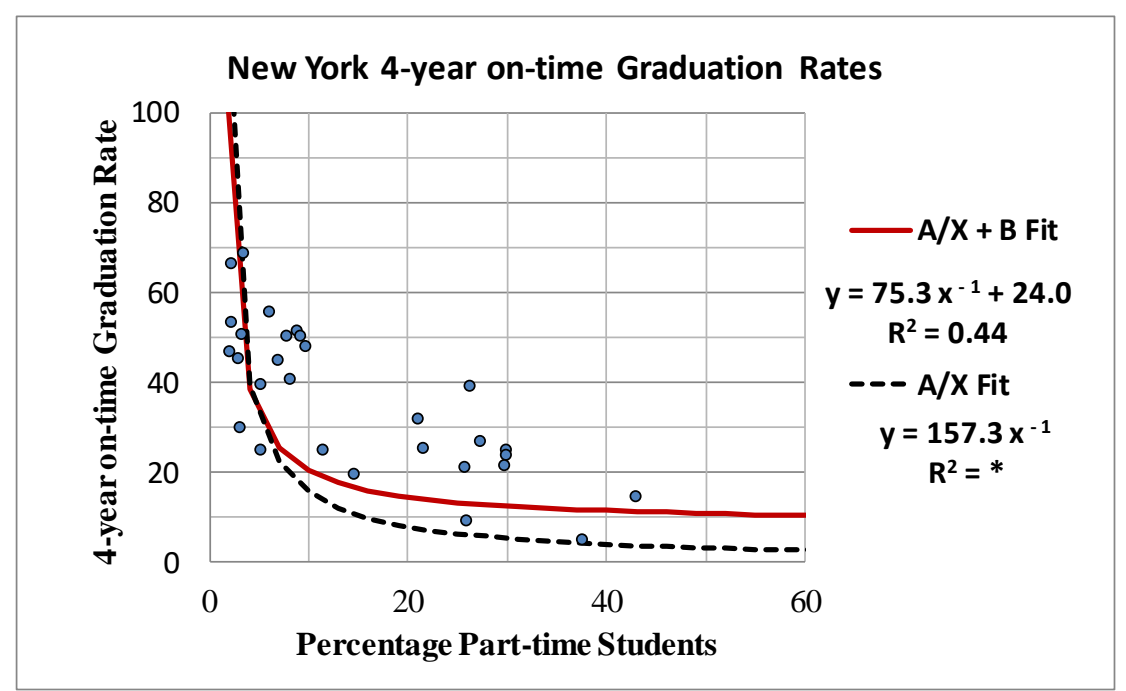

Figure 8b. Predicted on-time graduation rates for four-year New York institutions

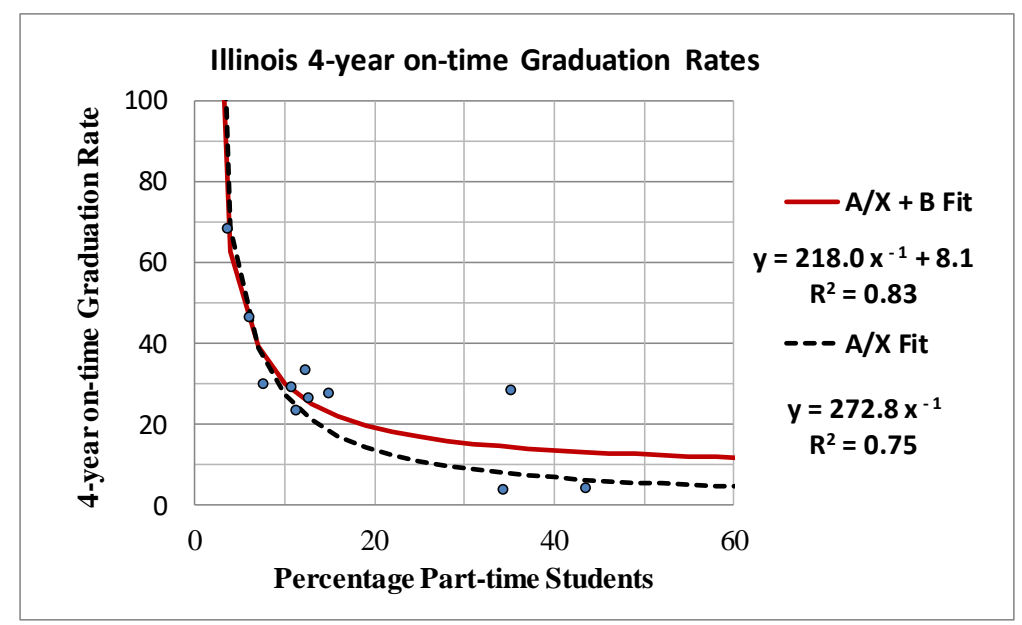

Figure 8c. Predicted on-time graduation rates for four-year Illinois institutions

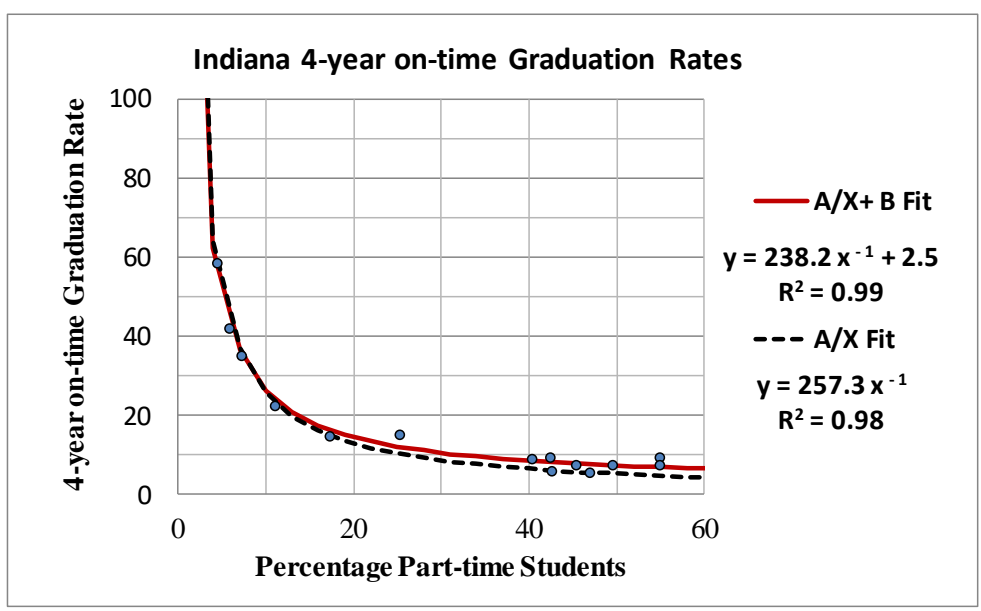

Figure 8d. Predicted on-time graduation rates for four-year Indiana institutions

2.2.6 A Longitudinal Examination of a Best-Case Model Prediction at the Institutional Level for One State

The one- and two-parameter models provided excellent predictions to on-time graduation rates from the percentages of part-time students, particularly for Idaho and Indiana. Idaho has only four institutions fitted by the models; however, Indiana has 14 institutions that have percentages of part-time students ranging from $4.4 \%$ to $55.0 \%$. Indiana has the 
largest number (eight) of institutions with percentages of part-time students greater than $40 \%$; Indiana's rather evenly distributed percentages of part-time students provides a good test for both the one- and two-parameter models.

To further determine whether this one-year data set was an anomaly for Indiana, 13 years (2002-2014) of data were examined for Indiana's 14 public four-year public institutions. They consisted of five research universities, eight regional masters/ baccalaureate campuses of two of the research (doctoral) universities, and one masters/baccalaureate institution. The one- and two-parameter models were both used to fit the 2002-2014 data; the results are shown in Figure 9. The model parameters are quite similar to the parameters of the Indiana data shown in Figure 8d. The institutions with percentages of part-time students less than about $35 \%$ have data trends that demonstrate how small annual reductions in the percentages of part-time students led to correponding higher graduation rates. The eight institutions that are regional campuses of the state's two largest doctoral/research universities do not exhibit smooth trends; this could be due to statistical fluctuations associated with the regional campuses that had 2010 student counts ranging from about 4,000 to 13,000 students while the state's two largest universities have between 30,000 and 37,000 student counts and correspondingly larger numbers of graduates.

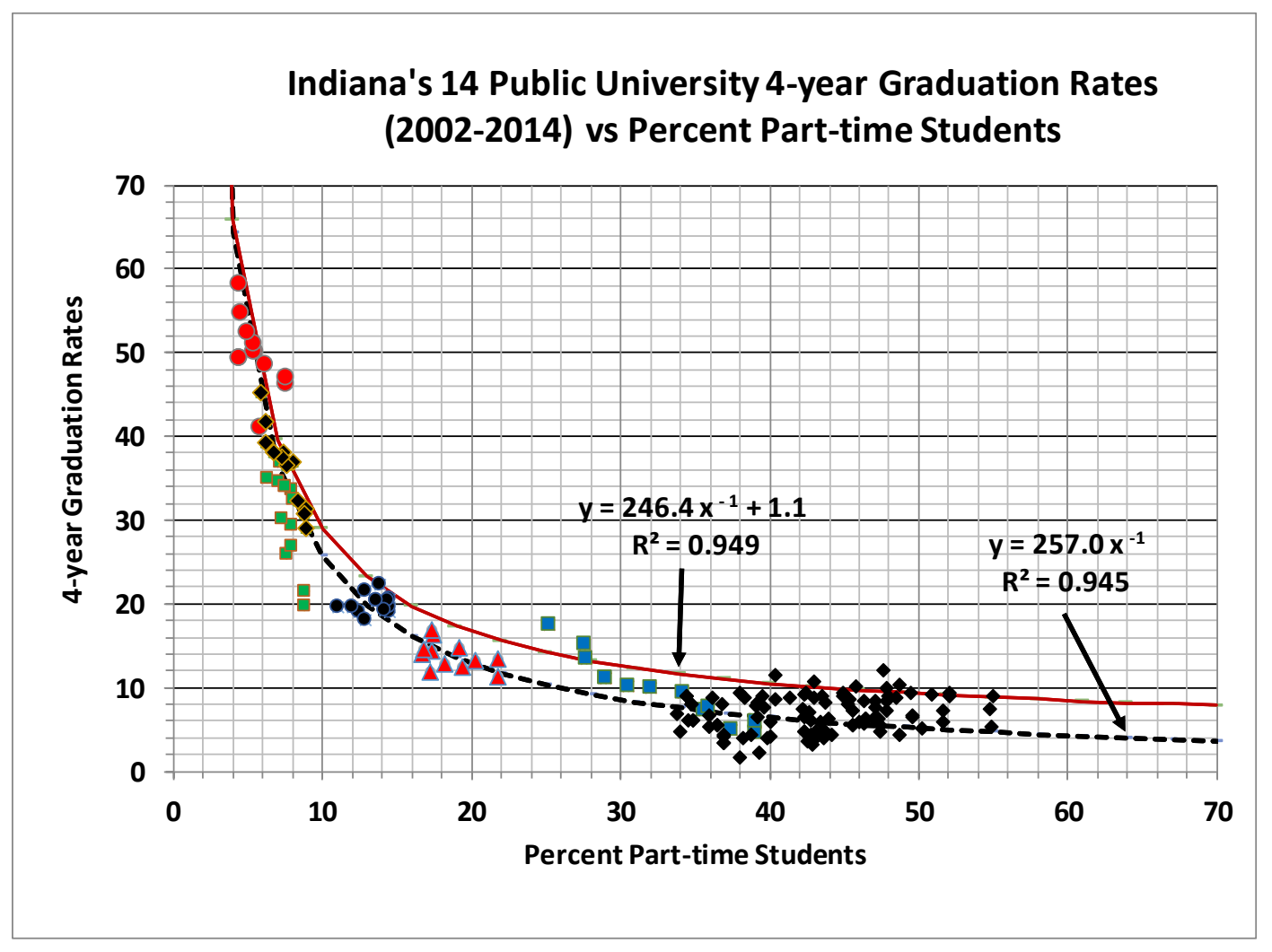

Figure 9. Predicted on-time graduation rates for 14 public four-year Indiana institutions

2.2.7 Which Is the Better Measure, Graduation Rates or Annual Numbers of Graduates in Two-Year Public Institutions?

How do the annual numbers of full-time first-time (FTFT) public community college two-year degrees granted compare to the total annual numbers of certificates and degrees awarded between 2004 and 2014? A related question is what was the effect of the 2007-2009 recession on enrollments and numbers of certificates and degrees awarded between 2012 and 2014 ?

These research questions became a political issue in the state of Indiana in May 2015 when a legislative delay was applied to capital funding requests at two community college sites in the state's public two-year system, Ivy Tech Community College. A legislator was informed by a "courtesy call" from the Bill and Melinda Gates Foundation that Indiana's community college system (that includes 14 regional sites) had the lowest graduation rate or was near the bottom (Horning, 2015). However, approximately 18 months later, the legislature (Colombo, 2016) lifted the delay.

In order to provide perspective to these two measures - annual numbers of FTFT public two-year degrees granted compared to the annual numbers of certificates and degrees awarded, Figure 10 displays these measures for the Ivy Tech Community College (2016) system of Indiana. This system/state was identified as having a low (or the lowest) graduation rate for FTFT students in the nation. (See Figure 1 and Appendix A, Table A1.) 
Using the 2013 (Figure 10) graduates and the corresponding enrollments for that year, a headcount of over 108,000 students (65.6\% part time and 34.4\% full time) earned 16,995 credentials (associate degrees and certificates). The 16,695 credentials consisted of 9,265 associate degrees and 7,730 certificates awarded to 13,118 unduplicated graduates. The numbers (and percent of graduates) associated with 2010 FTFT cohort group of 13,104 students had 328 (2.5\%) and $1159(8.8 \%)$ graduates, respectively, that graduated in 2 years (normal time, 100\%) and 3 years (150\%), respectively. The FTFT graduation rates of $2.5 \%$ and $8.8 \%$ produce at most 1159 associate degrees out of more than 9,265 earned in 2013 - or 12.5\%; likewise, the FTFT 13,104 cohort in 2010 represents a similar percentage (12.1\%) of the more than 108,000 total headcount in 2013

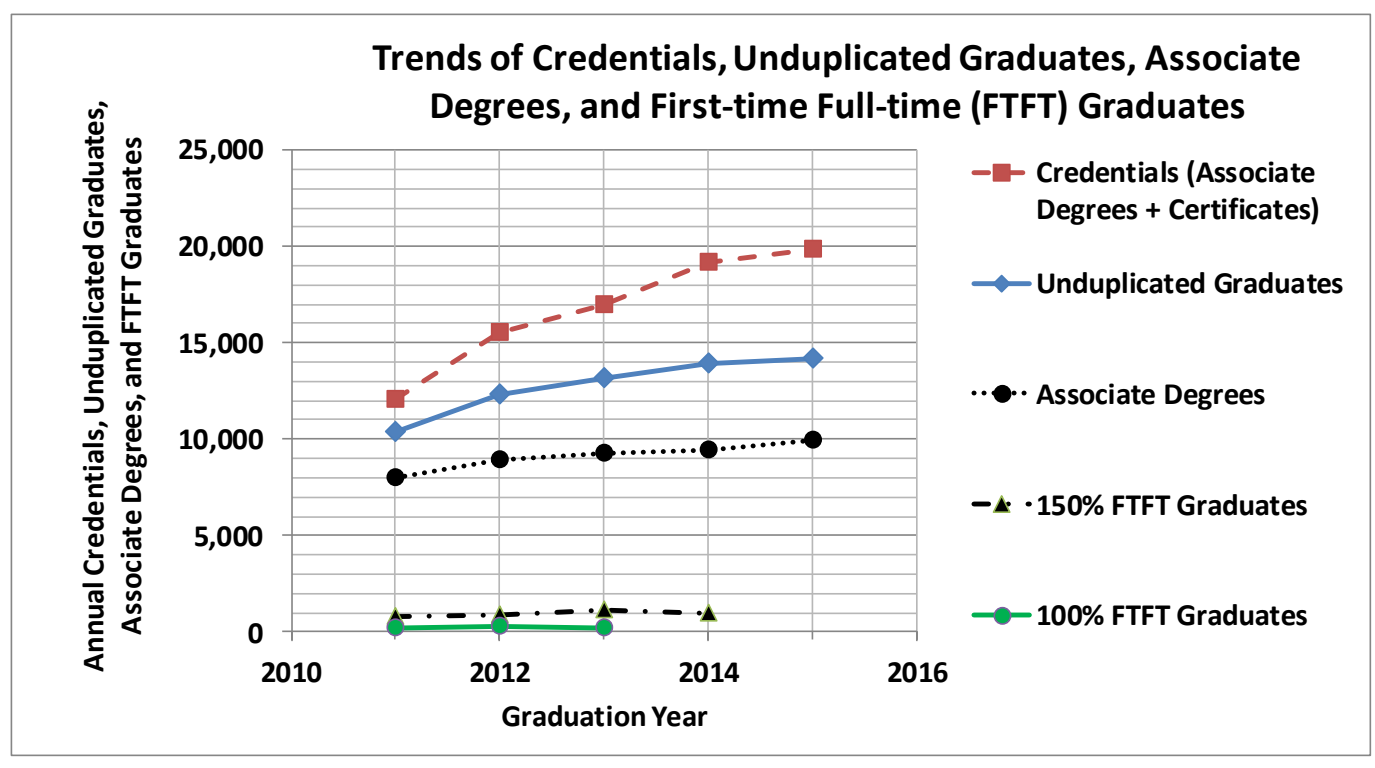

Figure 10. Trends in graduation rates by type of degree for Indiana institutions

One should further note four years in a row Community College Week (September 20, 2016) named Indiana's Ivy Tech Community College the top two-year institution in the awarding of associate degrees; the college awarded 9,954 in 2014-2015. This award recognizes the state's two-year community college system for its entire degree production successes rather than the FTFT cohort graduation rate that is just $12.5 \%$ of the degrees produced. Does this mean that one should ignore the very low FTFT graduation rates of 2.5\% and $8.8 \%$ ? Absolutely not!

The above comparisons show these low graduation rates have been in place at least since 2011, and the root cause of these low graduation rates have yet to be publicly identified and effectively treated. It is unfortunate that the numerous reform efforts attempted through legislative action and remedial plans of study for entering FTFT or first-time part-time students have failed to produce sustainable gains. Certainly, two-year institutions do not have the advantage of four-year institutions to adjust entrance requirements and obtain higher graduation rates.

The number of Indiana's community college graduates has varied over recent years due to the 2007-2009 recession and changing entrance requirements at the state's four-year schools. However, according to the IPEDS Trend Generator (National Center for Education Statistics, 2015), Indiana's 150\% 3-year community college graduation rates since 2005 (entering in fall 2002) have ranged from $8.0 \%$ to a high of $10.5 \%$ for the past nine years, a much longer trend than the 2011-2015 period shown in Figure 10. The following section contains the analysis of the semi-annual cohort data for 2009, 2010, and 2011 cohorts.

2.2.8 The Semester-by-Semester Decrease in a State's First-Time Full-Time Cohorts is Exponential

In the previous section it was shown that Indiana's two-year community college FTFT graduation rates for the 2010 cohort were either the lowest or nearly the lowest in the nation; the two-year 100\% normal time graduation rate was $2.5 \%$ and the 3 -year $150 \%$ normal graduation rate was $8.8 \%$. In order to examine the decrease in the annual IPEDS number of full-time cohorts enrolled each semester, the 2012-2015 "Fall End of Term" and "Spring End of Term" reports on the Ivy Tech Institutional Research website (2016) are used to obtain the IPEDS headcount of first-time full-time cohorts each semester from fall 2010 to the fall of 2014. Presented in Figure 11 are the 13,104 fall 2010 IPEDS cohorts' trend for that period. 


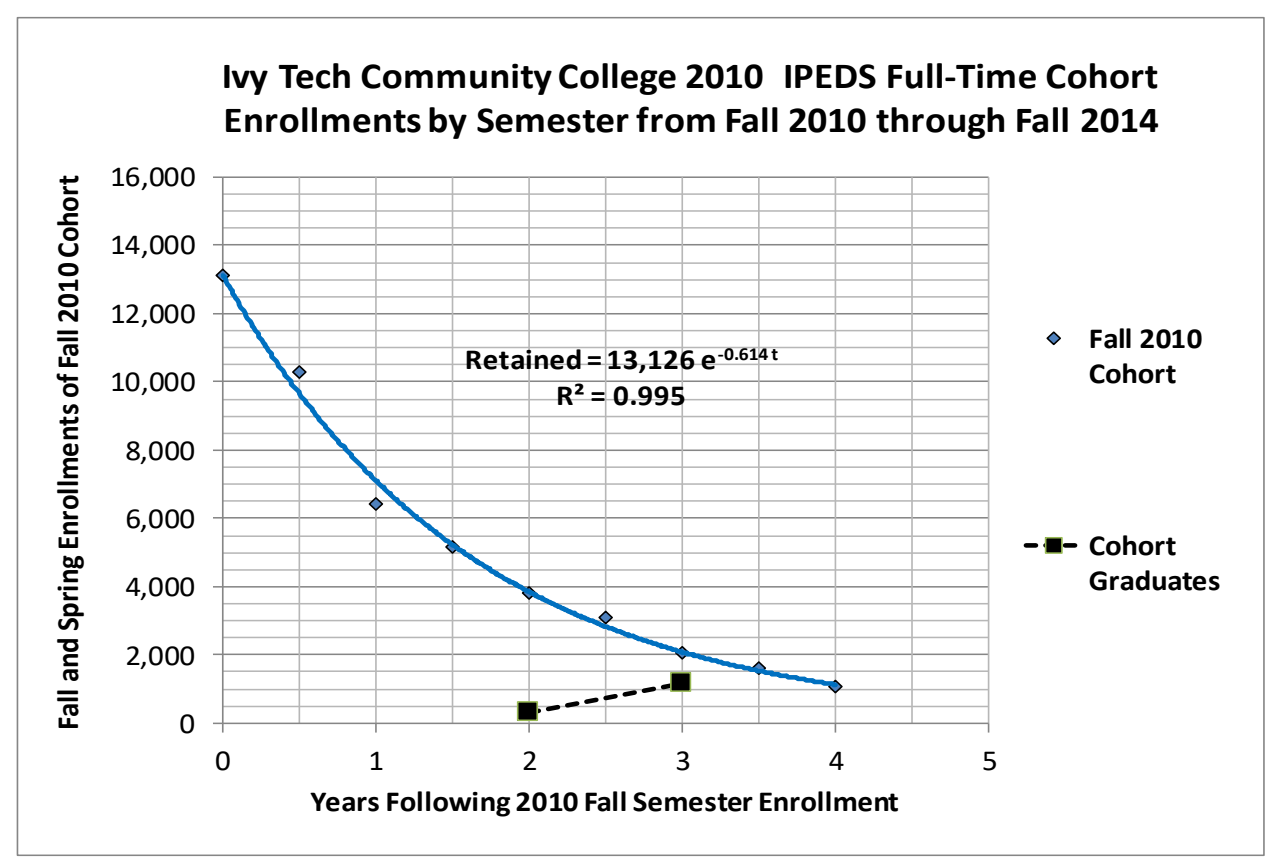

Figure 11. Exponential fit of graduation rates for Ivy Tech Community College

In Figure 11, the quality of fit to an exponential function over the nine semesters of data suggests that the probability of discontinuing after any given semester is nearly independent of time. Specifically for the fall 2010 cohort group the negative probability constant per year of $0.614 /$ year (or $0.307 /$ semester) that a member of the cohort will discontinue as a FTFT member of the cohort can be due to a number of reasons. These reasons can range from transferring to another educational institution, having to deal with a personal or family issue, or dropping out of school for academic reasons such as probation and/or academic disqualification. While the probabilities for each reason are additive in providing a single probability constant, it is somewhat surprising that the probability over time is nearly constant. (The probabilities for the 2009 and 2011 cohorts (and their associated $R^{2}$ values) are -0.579 (0.999) and - 0.629 (0.988), respectively.)

It should also be noted that when using exponential functions to describe growing or declining populations that the terms of doubling-time and half-life are often used to describe the time it takes for the population to double in size or shrink to one half. For the probability constant of 0.614/year in Figure 11, there is an associated half-life of 1.13 years (2.26 semesters). Graduation rate data for the fall 2011 cohort indicate that $2 \%, 8 \%$, and $16 \%$ of the cohort have graduated within the two-year (100\%), three-year (150\%), and four-year (200\%) times, respectively. Its half-life measure is 1.10 years ( 2.20 semesters) which is quite similar to the 2010 cohort results.

The exponential relationship that predicts cohorts retained may be useful in predicting cohort retention rates two to four years later from returning enrollments after just one and two semesters. When entrance requirements change and/or interventions initiated to improve graduation rates, one need not wait until a cohort has entirely graduated to estimate longer-term effects.

\subsubsection{Graduation Rates of FTFT Students in Four-Year Public Institutions Strongly Correlated With SAT Scores}

Colleges and universities have used SAT/ACT exam scores for many years to assist them in making admission decisions, and these same exam scores are often used as measures of the quality of their incoming classes. At the secondary level, currently 25 states use the SAT or ACT as part of their accountability assessments and as measures of college readiness (Gewertz, 2017). Therefore, it is worthwhile to (1) know how SAT scores influence graduation rates in four-year public institutions and (2) be able to predict prior to college entry the probability that students with specific demographics will graduate from four-year programs in four, five, and six years. The first issue, the relationship between SAT scores and four-year graduation rates, are presented followed by the second issue, graduation rate trajectories based on the graduation-rate data of DeAngelo, Franke, Hurtado, Pryor, and Tran (2011) are discussed.

2.2.10 Four-Year Institutional-Level Binned Data Show Strong Relationship Between SAT Scores and Graduation Rates

Again, the binned data of the 500 plus graduation rates of the four-year public institutions from the 50 states previously used in this study were used with corresponding median SAT scores to investigate their $100 \%$ (four-year) and $150 \%$ (six-year) of normal time on-time graduation rates (Chronicle of Higher Education College Completion project, 2012, 
and updated 2015). Presented in Figures 12a and 12b are the 2014 four-year and six-year graduation rates as a function of median SAT for public and private institutions, respectively.

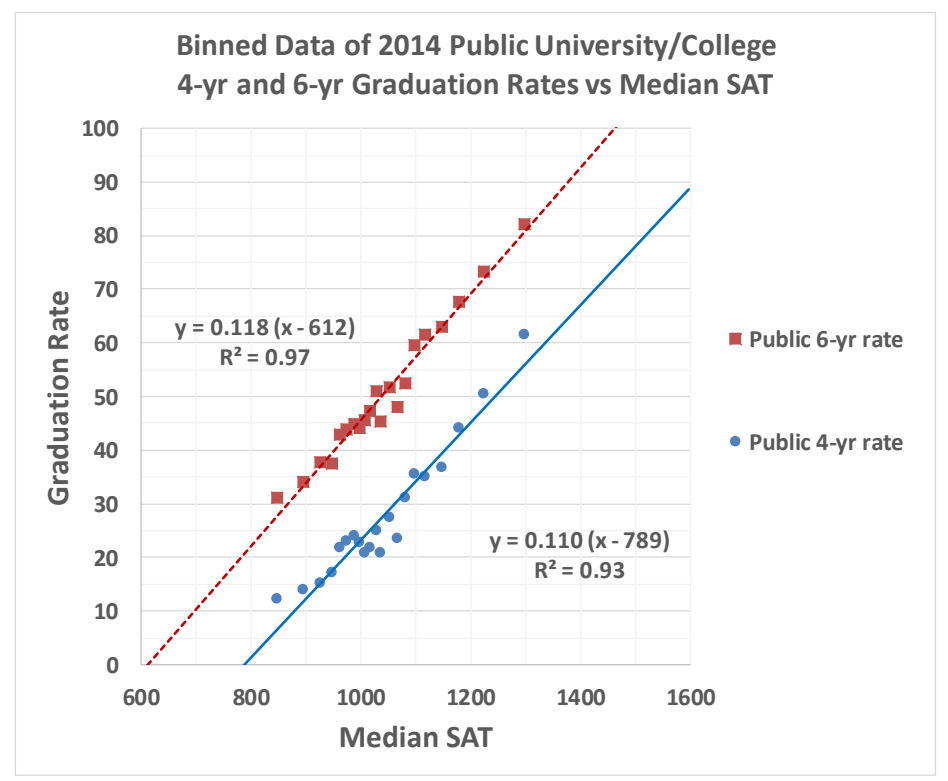

Figure 12a. Binned data of 2014 Public University/College Graduation Rates versus Median SAT

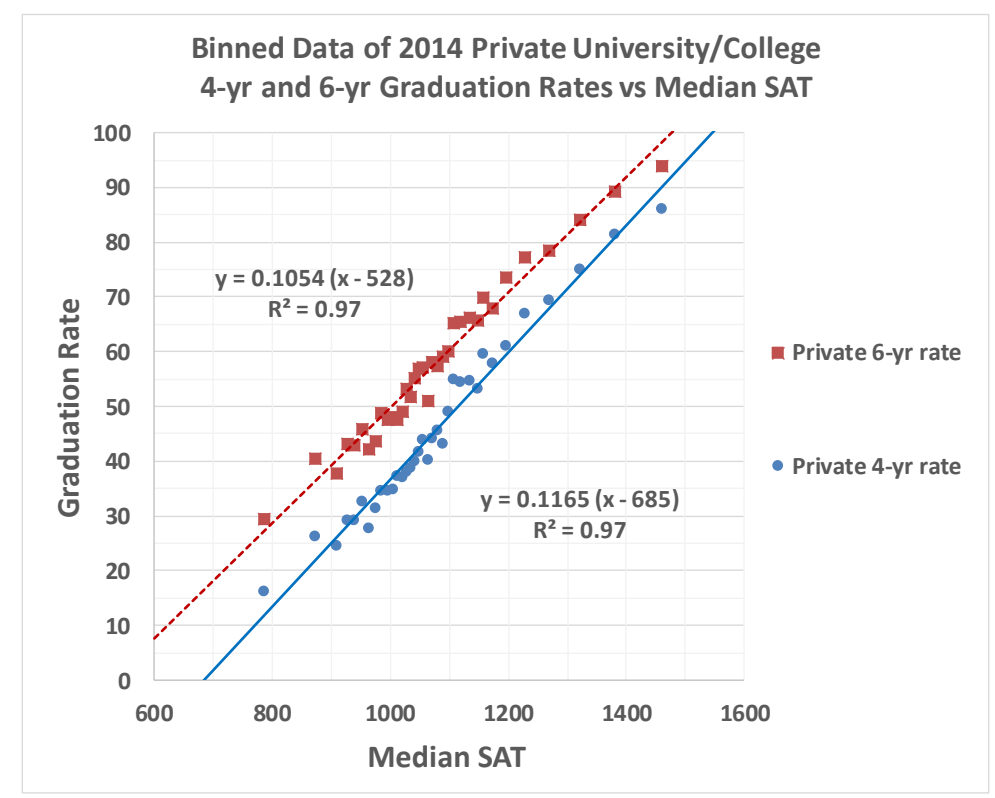

Figure 12b. Binned data of 2014 Private University/College Graduation Rates versus Median SAT

In Figure 12a, the public university/college slopes of the four-year and six-year graduation rate-median SAT trend lines are $11 \%$ and $12 \%$ increases in FTFT graduation rates, respectively, for each 100-point increase in median SAT. Although the focus of this study is on public institutions, it is interesting to note that the corresponding four-year and six-year private university/college trend line slopes in Figure 12b are 12\% and 11\% increases in FTFT graduation rates, respectively, for each 100-point increase in median SAT.

The binned trend lines of Figures 12a and 12b can estimate "average" FTFT graduation rates for median SAT scores from about 800 to 1400 . For example, at a median SAT of 800, the four-year public, four-year private, six-year public, and six-year private FTFT graduate rates are 1.2\%, 13.4\%, 22.2\%, and 28.6\%, respectively. At a median SAT score of 1400, these respective trend line graduation rates are 67.2\%, 83.3\%, 93.0\%, and 91.6\%. (See Appendix D where Table D1 and Figures D1a and D1b provide additional graduation rates for median SATs between 800 and 1400, and alternative comparisons of public and private institutions for four-year and six-year graduation rates.) 
Similar graduation rate-SAT comparisons for individual states illustrate differences in slope from state to state. It also becomes evident that metropolitan campuses and the branch campuses of the flagship universities often have lower graduation rates (and lower median SAT scores); these in turn provide state graduation rates and median SAT trend lines that are steeper. For example, 100-point SAT increases in the public universities of Ohio, Illinois, Indiana, and Michigan are associated with four-year graduation rate increases of 13\%,15\%,15\%, and 16\%, respectively, compared to a national average of $11 \%$ (see Figure 12a). (In Appendix D, see Table D2 and Figures D2a and D2b for the four-year graduation rate vs median SAT scores of FTFT students for Ohio, Illinois, Indiana, and Michigan.)

2.2.11 Comparison of $100 \%$ and $150 \%$ Normal-Time Graduation Rates for FTFT Students in Two-Year and Four-Year Institutions

From the above, the graduation rates of four-year public and private institutions on average are highly influenced by the SAT scores of their students where a 100-point increase in SAT scores typically yields an 11- to 12-percentage point increase in graduation rates. Although 25 states currently use ACT/SAT assessments for their secondary students, very few states with public two-year public institutions require or collect SAT information. Therefore, reliable median SAT-graduation-rate comparisons of the type just made for public four-year institutions are difficult to make for two-year institutions. However, 14 public two-year institutions (from six states) out of the more than 900 two-year public institutions studied in this investigation provided median SAT scores with their $100 \%$ and $150 \%$ FTFT graduation rates; these are shown in Figures 13a and 13b, respectively.

The two-year 100\% on-time graduation rates ranged from about $5 \%$ to over $20 \%$ with median SAT scores ranging from about 750 to 1050; their graduation-rate average and associated median SAT score were about $12 \%$ and 900 , respectively. The corresponding three-year $150 \%$ on-time graduation rates averaged about 20\%. In both Figures 13a and $13 \mathrm{~b}$ the median-SAT/graduation-rate trend lines exhibited a weak correlation $\mathrm{r}=0.34$ ); furthermore, a 100-point increase in median SAT score for two-year institutions produced only a 2.7 and 3.5 percentage-point increase for the two- and three-year graduation rates, respectively.

As can be seen in Figure 13a, the 100\% two-year average of a median SAT of 900 and $12 \%$ graduation rate is quite similar to the four-year $100 \%$ median SAT trend line at 900 that is $12.2 \%$. However, the $150 \%$ two-year and four-year graduation rates at 900 are quite different at $20 \%$ and 34\%, respectively (see Table D1 Appendix D). Therefore, one additional year to achieve a two-year graduation does not yield as big a percentage gain in graduation rate as two additional years in achieving a four-year degree.

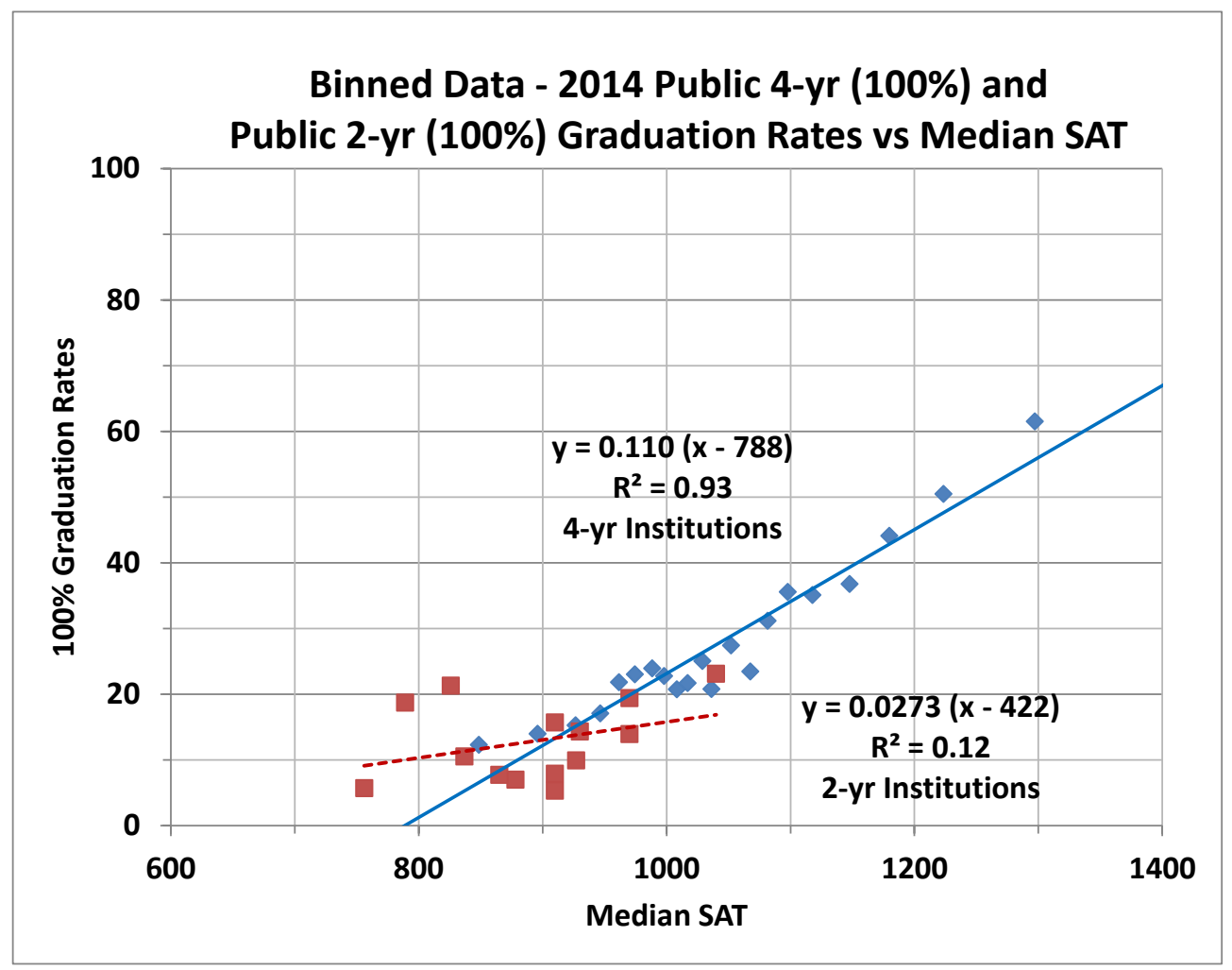

Figure 13a. Binned data of 2014 Public University/College On-time Graduation Rates versus Median SAT 


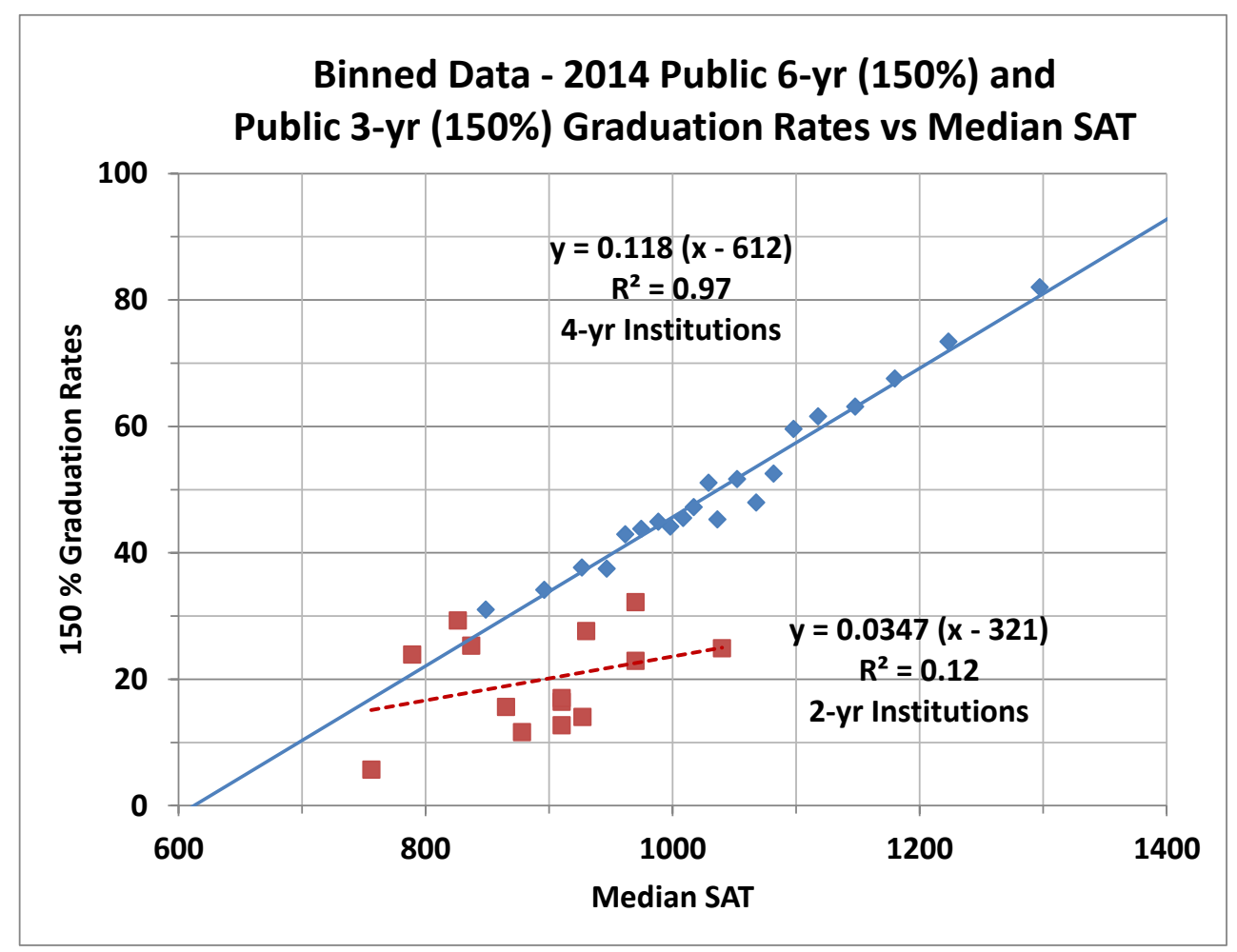

Figure 13b. Binned data of 2014 Public University/College 150\% Graduation Rates versus Median SAT2.2.12 HERI Logistic Graduation-rate Model Predicts Graduation-rate Trajectory Measures from Empirical Data

Spurred by declining graduation rates during the previous decade for all types of students in four-year institutions, particularly in public institutions, Astin and Oseguera (2005) of the Higher Education Research Institution (HERI) at the University of California Los Angeles (UCLA) conducted a study of four-year and six-year completion rates for first-time full-time students. Using a database of 56,818 students entering as freshmen in the fall of 1994 from 262 bachelor's degree granting institutions, they used linear regression models to predict expected graduation rates. Their results indicated that two-thirds of the variations in graduation rates between institutions were due to student characteristics; therefore, differences between model predictions made it possible to assess the effectiveness of an institution's retention programs.

DeAngelo, Franke, Hurtado, Pryor, and Tran, (2011) at HERI (UCLA), extended the work of Astin and Oseguera (2005). Using their CIRP data from 201,056 FTFT students at 356 non-profit institutions, the researchers merged the characteristics of the entering students' high school academic achievement, attitudes, and family variables (from their CIRP data) with National Student Clearinghouse (Shapiro et al., 2015) graduation rates at four-, five-, and six-years. Again, logistic models, which included student demographics and student attitudes, predicted degree-completion rates at four-, five-, and six-years.

2.2.13 Student Probability Formula for Predicting Graduation Rates Also Predicts Graduation-Rate Trajectory Measures for Institutions or Students With Like Characteristics

The graduation rate calculator of DeAngelo et al. (2011) is a logistic growth model where the probability of graduation $\mathrm{Y}(\mathrm{X})$ at four, five, or six years expressed in the following manner:

$$
\mathrm{Y}(\mathrm{X})=\exp (\mathrm{X}) /(1+\exp (\mathrm{X}))
$$

where the variable $\mathrm{X}$ is computed at four, five, or six years from a logistic regression, and is given by

$$
\mathrm{X}=\mathrm{a}+\mathrm{B}_{1} \mathrm{X}_{1}+\mathrm{B}_{2} \mathrm{X}_{2}+\ldots+\mathrm{B}_{\mathrm{i}} \mathrm{X}_{\mathrm{i}} \text {. }
$$

The logistic regression determines the constant " $\mathrm{a}$ " and corresponding $\mathrm{B}_{\mathrm{i}}$ values which are regression coefficients associated with the independent variables $\mathrm{X}_{\mathrm{i}}$.

\subsubsection{Interactive-Engagement Model Graduation-Rate Trajectories}

Using the learning theory work of Bao (2007) and Pritchard, Lee, and Bao (2008), Ober and Beekman (2016) developed vocabulary-learning trajectories from an interactive engagement equation of learning that had a solution in the form of 
Equation 3. For example, writing Equation 3 as a function of time, the graduation rates $\mathrm{Y}(\mathrm{t})$ in years four, five, and six is represented by a three-parameter logistic growth model as follows:

$$
\mathrm{Y}(\mathrm{t})=1 /(1+\exp (-\mathrm{t}))=\mathrm{C}_{\max } /\left[1+\left(\exp \left(-\alpha\left(\mathrm{t}-\mathrm{t}_{1 / 2}\right) / \mathrm{C}_{\max }\right)\right]\right.
$$

where $C_{\max }$ is the maximum graduation rate achieved, $\alpha$ is a growth parameter, and $t_{1 / 2}$ is the time that $Y(t)$ has a value of $\mathrm{C}_{\max } / 2$, the inflection point of the trajectory. This function is an S-shaped curve with a slow initial growth rate, followed by a more rapid rate around the inflection point $\mathrm{t}_{1 / 2}$, and then followed by another region of slow growth.

Using the four-, five-, and six-year graduation-rate data of DeAngelo et al. (2011), we compute families of three-parameter graduation-rate trajectories using Equation 3. The computed trajectories are for seven high-school grade point averages (from $\mathrm{C}$ to $\mathrm{A}+$ ) and seven composite SAT scores (less than 800 to 1300+). Presented in Figures $14 \mathrm{a}$ and $14 \mathrm{~b}$, respectively, are both families of data for the times of zero through eight years. Presented in Table E1 of Appendix E are the DeAngelo et al. (2011) HSGPA and SAT data, respectively, and the three interactive engagement parameters obtained for each family of trajectories - the maximum graduation rate $C_{\max }$, the time $t_{1 / 2}$ to reach half the maximum graduation rate, and the growth constant $\alpha$. See Appendix F, for a discussion of some properties of logistic curves.

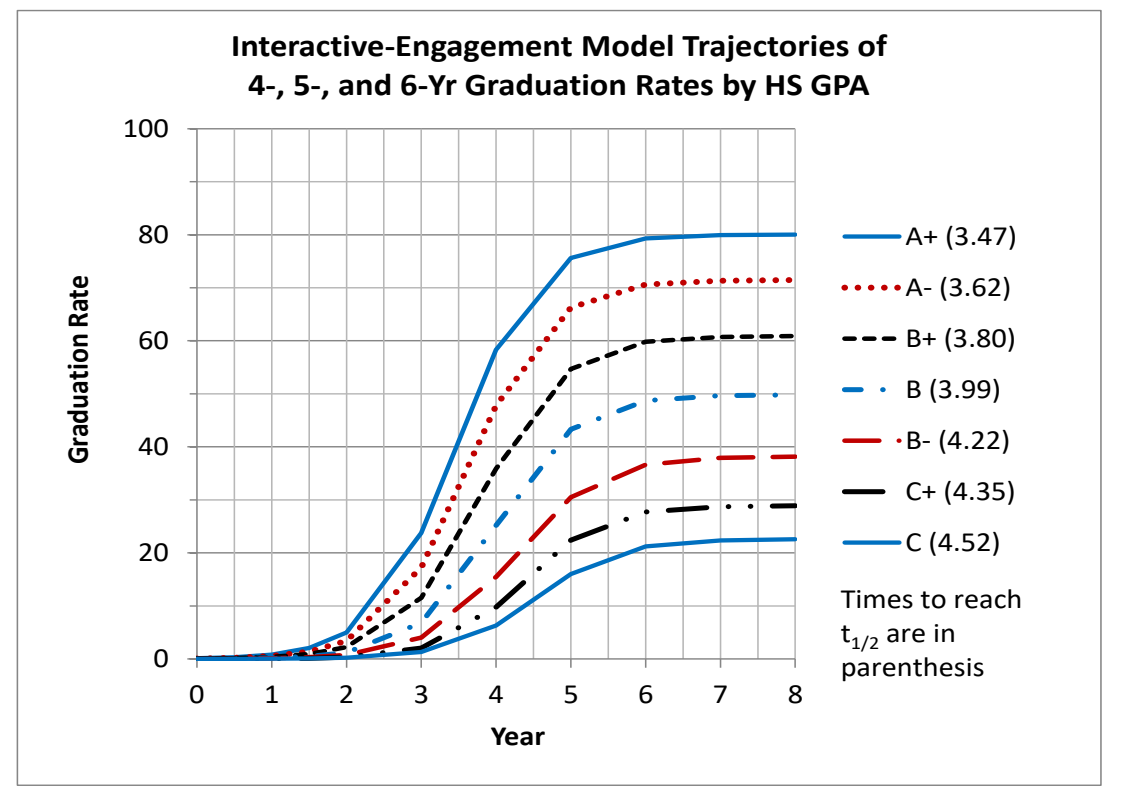

Figure 14a. Trajectories of four-, five-, and six-year graduation rates by high school GPA

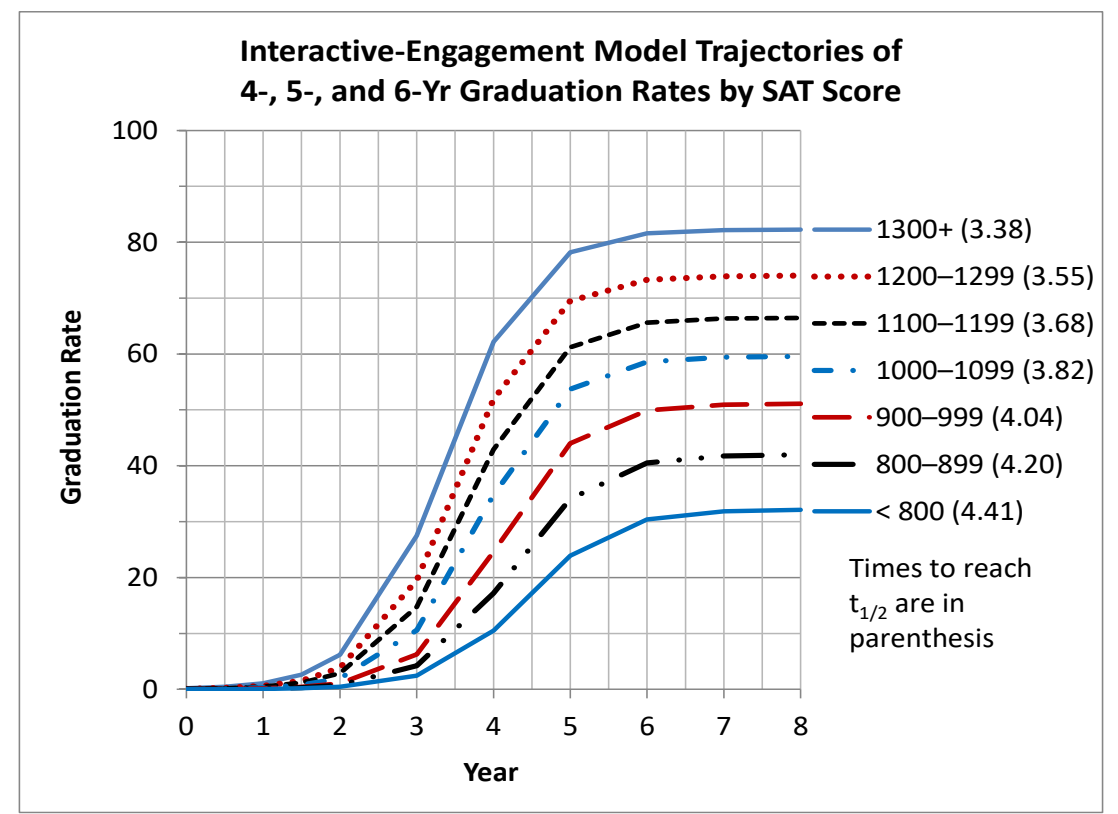

Figure 14b. Trajectories of four-, five-, and six-year graduation rates by SAT score 
Families of graduation rate trajectories like those in Figures 14a and 14b (and Table E1) convey not only four-, five-, and six-year graduation-rates, but they also predict rates at later times (say eight years, at 200 percent of normal time). These vivid depictions allow one to make quick visual comparisons of institutional data; for example, one can further ask questions concerning whether an institution's graduation rates are characteristic of its entering classes' SAT scores and/or HSGPAs.

Figure 9 displays Indiana's four-year graduation rates versus percentages of part-time students for its 14 public universities for 2002-2014. In this figure, a group of similar institutions fell within a range of FTFT graduation rates of less than $2 \%$ to $12 \%$ and a range of part-time percentages of $34 \%$ to $55 \%$. These similar institutions were the masters and baccalaureate institutions that are the regional campuses of the state's two "research very high" institutions as classified by the Carnegie Foundation (2011). In Figure 9, the institutions with the higher graduation rates (and corresponding lower percentages of part-time students) are the state's public research and doctoral institutions. When the four-, five-, and six-year graduation rate trajectories for Indiana's research and doctoral institutions are displayed for the 2010 cohort in Figure 15a (like those in Figures 14a and 14b), one sees that some of the separations between these similar institutions can be due to the HSGPAs and composite SAT scores of the incoming classes. When the four-, five-, and six-year graduation rates for the nine regional campuses of the "bachelor's and master's" institutions are presented in Figure 15b, this also clearly demonstrates that HSGPA and composite SAT scores are highly correlated with graduation rates when compared to Figures $14 \mathrm{a}$ and $14 \mathrm{~b}$, respectively.

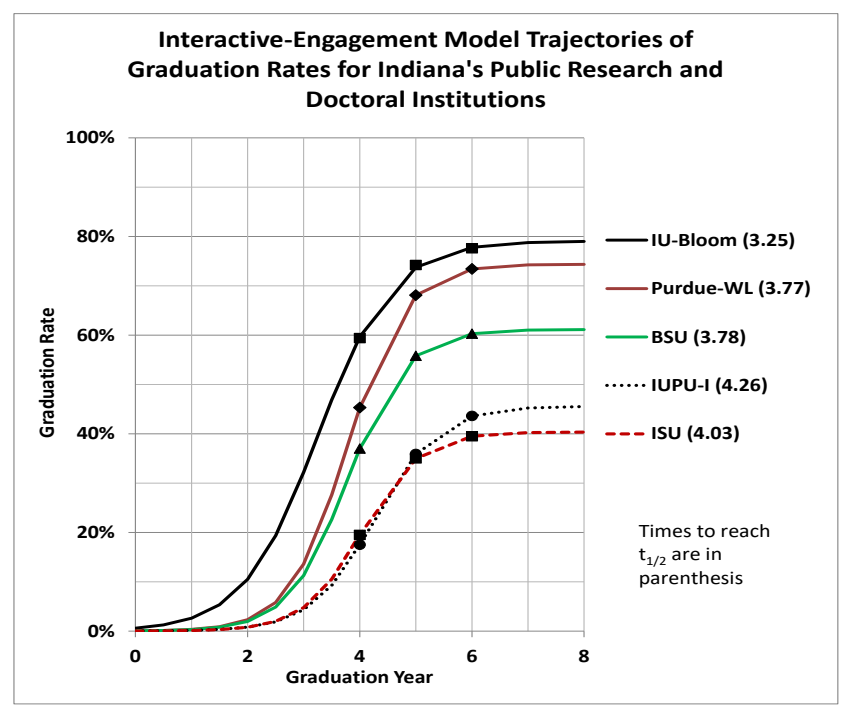

Figure 15a. Trajectories of graduation rates for Indiana's public research and doctoral institutions

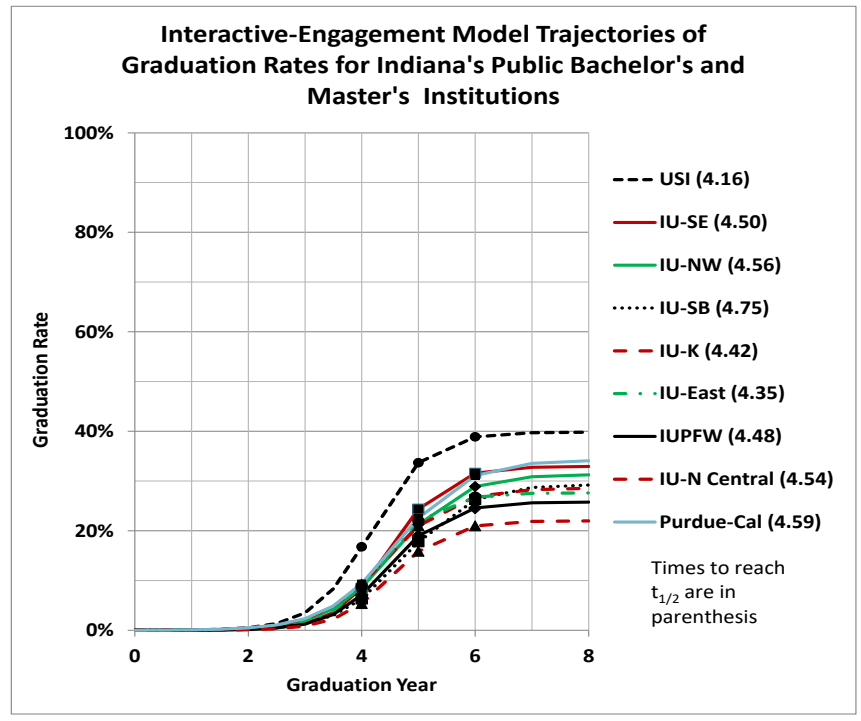

Figure 15b. Trajectories of graduation rates for Indiana's public bachelor's and master's institutions 


\section{Evidence Supported Conclusions and Discussion}

Pertinent to the first research question was identifying the states with the highest and lowest graduation rates for FTFT two-year public community colleges. South Dakota and Indiana had the highest and lowest rates, respectively, with rates of $51.2 \%$ and $8.8 \%$ for $150 \%$ of normal times (see Table A1 in Appendix A). Indiana's four-year $150 \%$ rate of $55.2 \%$ was slightly larger than South Dakota's $50.5 \%$ rate with ranks among the 50 states of $25^{\text {th }}$ and $34^{\text {th }}$, respectively (see Table A2 in Appendix A). The highest and lowest four-year 150\% rates were associated with Delaware (73.6\%) and Alaska (30.6\%), respectively. Yet their two-year rates of $14.4 \%$ (Delaware) and $27.0 \%$ (Alaska) ranked $37^{\text {th }}$ and $8^{\text {th }}$, respectively (see Tables A1 and A2 of Appendix A). These four sets of results are consistent with the result that there is no correlation between a state's two-year and four-year cohort graduation rates (see Figure 1).

The second research question examined FTFT two-year and four-year graduation rates and their associated percentages of part-time students. As shown in Table B1 of Appendix B, South Dakota had one institution with less than 20\% part time, and four institutions with percentages of part-time students between $20 \%$ and $40 \%$; Indiana had vastly different two-year percentages of part-time students with all of its students in the range of $60 \%$ and $80 \%$ part-time students. Similarly, the highest four-year graduation rates of Delaware were associated with its two institutions that had less than $20 \%$ part-time students. Again, Alaska, the state with the lowest four-year graduation rate had high percentages of part-time students (see Table B2 in Appendix B). These four sets of data are consistent with an inverse relationship between on-time graduation rates and percentages of part-time students.

The authors verified this inverse mathematical relationship between graduation rates and percentage of part-time students that was consistent with this intuitive relationship just introduced. See Figure 2 for the national graduation rates for 2-year and 4-year schools. The 50-state two-year and four-year graduation rates versus percentages of part-time students (Figures 4 and 5) demonstrates that part-time student percentages can predict graduation rate trends.

The authors further investigated the inverse relationship between graduation rate and percentage of part-time students for all 50 states. See Figures 8a-8d for representative results for four states. (Appendix C contains a summary of the 50 states.) The graduation rates and percentages of part-time students for Indiana's 14 public institutions showed longitudinally in time (2002-2014) that the general trends of small annual improvements were typically associated with small decreases in part-time percentages. Also, note that high school graduation rates improved over the past decade (Ritter, 2015).

In order to provide a perspective on the number of FTFT students entering each year and the (cohort) graduates, the authors presented a comparison of these numbers to the total number of students served and graduating annually. While these FTFT numbers are important for accountability (say in performance-based funding), Student Right-to-Know purposes, and research purposes such as this study, the big-picture of success stories that are occurring each year are not essential since the extremely low FTFT graduation rates that have been occurring for many years explains the entire system.

The results shown in Figure 10, which shows numbers rather than rates, best summarizes this perspective. For example, in Indiana in the fall 2010 a large FTFT cohort group of 13,104 students graduated $328(2.5 \%)$ and 1,159 (8.8\%) students in two years and three years, respectively. Compare the numbers to 108,000 system students and 16,995 graduates who earned credentials (associate degrees and certificates) in 2013. Also, note that fluctuations in both graduation numbers and graduation rates could be associated with state unemployment rates that occurred between 2007 and 2015.

Faculty convocations typically take place at the beginning of each academic year to provide college and university communities with a thumbnail sketch of recent achievements by students and faculty, as well as enrollment data and scholastic information about the entering class. Everyone knows when average SAT scores of the entering class have higher scores then higher graduation rates are the result and hopefully favorable future Best College listings by the U.S. News \& World Report; better yet, there will be higher graduation rates and other institutional measures that will result in larger bonuses in the state's performance-based funding formula.

Strange as it may sound, faculty fully understand the cause and effect relationship between SAT scores and graduation rates, yet, it is unlikely that the majority of the faculty will remember much beyond the overall composite SAT score of the incoming class, and whether it went up (or down) a few points with the newly arriving class. However, university presidents and administrators understand fully the changes in the academic quality and social conditions of the student life for the campus when entrance requirements (SAT cut scores or HSGPAs) are raised and influence the size of the incoming class by 10 to 20 percentage points.

The fourth research question entailed determining the extent of the influence that SAT scores had on the graduation rates of FTFT cohort students in four-year public institutions. After investigating this relationship for a number of states, 
the authors studied the 500 plus four-year public institutions by binning the data. The four-year and six-year graduation rates as a function of median SAT scores for both public and private institutions revealed increases of approximately 11 percentage points for each 100-point increase in median SAT score (see Figures 12a and 12b). The data of DeAngelo et al. (2011) have similar trends of approximately 9 percentage points for each 100-point increase in median SAT score (see Table E1 in Appendix E). The binned data and the DeAngelo data both confirm that for median SAT scores of 800 or lower one expects very low on-time graduation rates.

Unless two-year institution applicants are planning to enroll in special academic programs or to transfer general education and introductory courses to a state four-year public institution, very few two-year institutions require SAT or ACT scores for admission. Therefore, the amount of data for two-year graduation rates and SAT scores for FTFT graduates are limited. However, out of the 900 plus two-year institutions used in this investigation, there were 14 institutions from eight states with SAT data that were compared to the binned public institution data of the four-year institutions (see Figures 13a and 13b).

The 100\% on-time graduation rates of the 14 two-year and binned four-year institutions (Figure 13a) have trend lines that cross at a median SAT score of 909 and a graduation rate of $13.3 \%$. This would suggest that the two-year graduates with these SAT scores and higher are capable of graduating from four-year programs.

\section{Addendum}

Dave Ober passed away September 6, 2017. It has been an honor to work with Dave. He initiated this paper and worked tirelessly on it. Dave's work includes the excellent graphs and much of the explanation. Without his efforts, this paper would not have evolved. Dave had a 39-year career as a Physics Professor, with the last 16 years as Chair of the Department of Physics and Astronomy.

\section{References}

Astin, A. W., \& Oseguera, L. (2005). Degree Attainment Rates at American Colleges and Universities. Revised Edition. Los Angles: Higher Education Research Institution, UCLA.

Bao, L. (2007). Dynamic models of learning and education measurement. arXiv preprint arXiv:0710.1375. http://arxiv.org/ftp/arxiv/papers/0710/0710.1375.pdf

Beekman, J. A. (1984). Demography through problems. Springer-Verlag, New York.

Carnegie Foundation for the Advancement of Teaching (2011). The Carnegie Classification of Institutions of Higher Education, 2010 edition, Menlo Park, CA: Author.

Chronicle of Higher Education College Completion project (2012 and updated 2015). Who graduates from college, who doesn't, and why it matters. Retrieved from http://collegecompletion.chronicle.com/

Coletta, V. P., \& Phillips, J. A. (2005). Interpreting FCI scores: Normalized gain, preinstruction scores, and scientific reasoning ability. American Journal of Physics, 73(12), 1172-1182. https://doi.org/10.1119/1.2117109

Colombo, H. (2016, November). Legislature poised to end Ivy Tech construction ban. Indianapolis Business Journal. Retrieved from http://www.in.gov/che/files/December\%202016\%20Commission\%20Meeting\%20Agenda.pdf and from https://www.ibj.com/articles/61123-legislature-poised-to-end-ivy-tech-construction-ban

Community College Week: Associate Degrees: All Disciplines — Grand Total (September 20, 2016). Retrieved from http://ccweek.com/articles.sec-28-1-deep-data.html

DeAngelo, L., Franke, R., Hurtado, S., Pryor, J. H., \& Tran, S. (2011). Completing college: Assessing graduation rates at four-year institutions. Los Angeles: Higher Education Research Institute, UCLA.

Gewertz, C. (2017). Which States Require Students to Take the SAT or ACT? An Interactive Breakdown of States' 2016-17 Testing Plans (May 2, 2017). Education Week. Retrieved from http://www.edweek.org/ew/section/multimedia/states-require-students-take-sat-or-act.html

Horning, P. (2015, May 29). Lackluster Ivy Tech Data Prompts Statehouse Funding Freeze. Indiana Public Media. Retrieved from http://indianapublicmedia.org/news/lackluster-ivy-tech-data-prompts-statehouse-funding-freeze-82782/

Ivy Tech Institutional Research (2016). Retrieved from: https://www.ivytech.edu/institutionalresearch/

National Center for Education Statistics (2015). Retrieved from https://nces.ed.gov/programs/digest/d15/tables/dt15_303.60.asp 
https://nces.ed.gov/programs/digest/d15/tables/dt15_326.10.asp https://nces.ed.gov/programs/digest/d15/tables/dt15_326.20.asp

Ober, D. R., \& Beekman, J. A. (2016). Dynamic Models of Learning That Characterize Parent-Child Exchanges Predict Vocabulary Growth. Journal of Education and Training Studies, 4(4), 9-26. https://doi.org/10.11114/jets.v4i4.1215

Pritchard, D. E., Lee, Y. J., \& Bao, L. (2008). Mathematical learning models that depend on prior knowledge and instructional strategies. Physical Review Special Topics-Physics Education Research, 4(1), 010109.

https://doi.org/10.1103/PhysRevSTPER.4.010109

Ritter, B. (2015). Factors Influencing High School Graduation (Issue Brief Prepared for the Washington Student Achievement Council). Retrieved from state of Washington website http://www.wsac.wa.gov/sites/default/files/2015.12.3.Ritter.Graduation.Issue.Brief.pdf

Shapiro, D., Dundar, A., Wakhungu, P.K., Yuan, X., Nathan, A., \& Hwang, Y. (2015, November). Completing College: A National View of Student Attainment Rates - Fall 2009 Cohort (Signature Report No. 10). Herndon, VA: National Student Clearinghouse Research Center.

\section{Appendix A}

Table A1. State two-year Public Community College 100\% and 150\% Normal-time Graduation Rates, and Percentages of Part-time Students

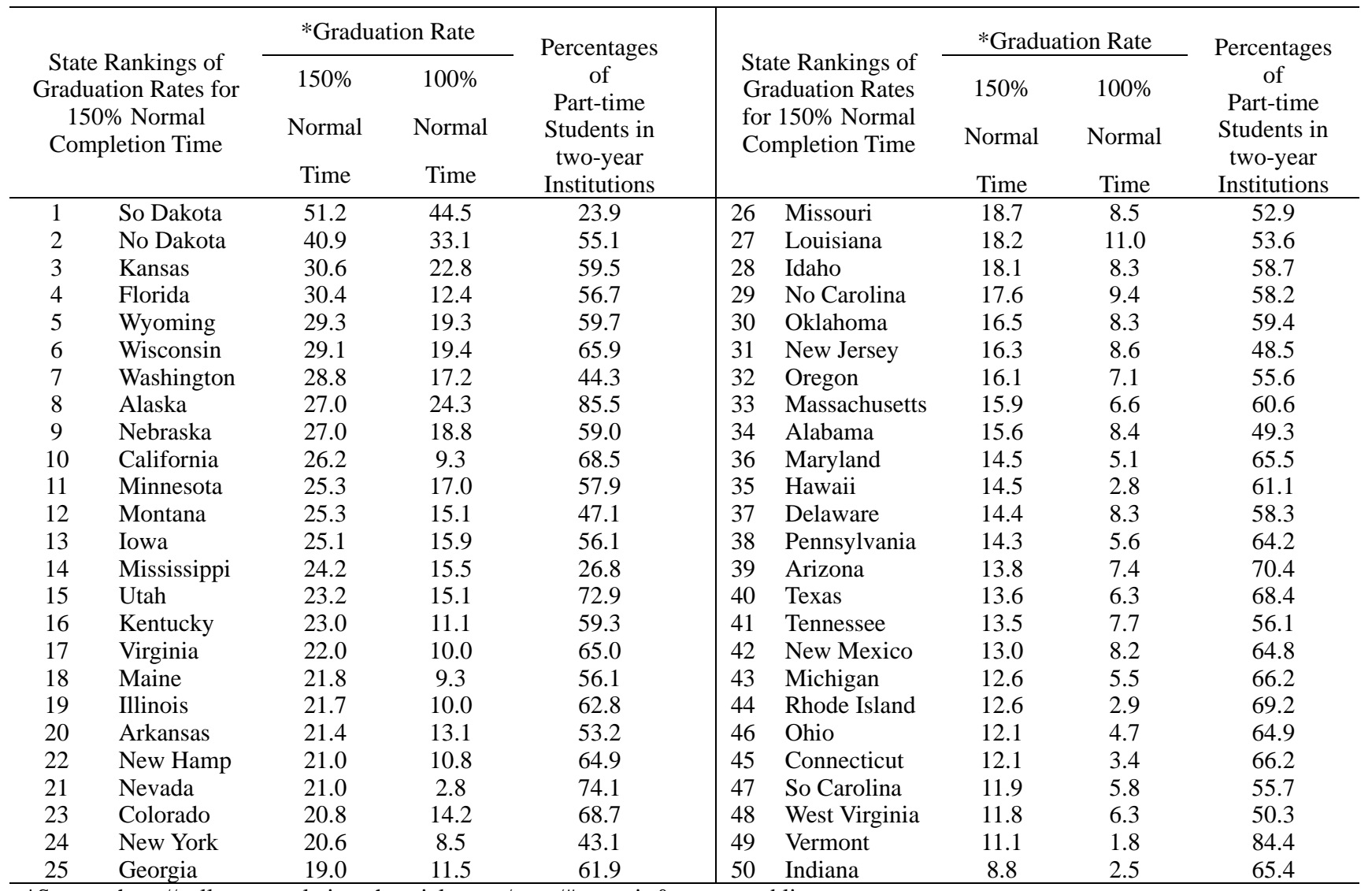

*Source: http://collegecompletion.chronicle.com/state/\#state=in\&sector=public_two 
Table A2. State four-year Public University 100\% and 150\% Normal-time Graduation Rates, and Percentages of Part-time Students

\begin{tabular}{|c|c|c|c|c|c|c|c|c|c|}
\hline \multirow{4}{*}{\multicolumn{2}{|c|}{$\begin{array}{l}\text { State Rankings of } \\
\text { Graduation Rates } \\
\text { for } 150 \% \text { Normal } \\
\text { Completion Time }\end{array}$}} & \multicolumn{2}{|c|}{ *Graduation Rate } & \multirow{4}{*}{$\begin{array}{l}\text { Percentages of } \\
\text { Part-time } \\
\text { Students in } \\
\text { four-year } \\
\text { Institutions }\end{array}$} & \multirow{4}{*}{\multicolumn{2}{|c|}{$\begin{array}{l}\text { State Rankings of } \\
\text { Graduation Rates } \\
\text { for } 150 \% \text { Normal } \\
\text { Completion Time }\end{array}$}} & \multicolumn{2}{|c|}{ *Graduation Rate } & \multirow{4}{*}{$\begin{array}{c}\text { Percentages of } \\
\text { Part-time } \\
\text { Students in } \\
\text { four-year } \\
\text { Institutions }\end{array}$} \\
\hline & & \multirow{3}{*}{$\begin{array}{c}150 \% \\
\text { Normal } \\
\text { Time }\end{array}$} & \multirow{3}{*}{$\begin{array}{c}100 \% \\
\text { Normal } \\
\text { Time }\end{array}$} & & & & $150 \%$ & $100 \%$ & \\
\hline & & & & & & & Normal & Normal & \\
\hline & & & & & & & Time & Time & \\
\hline 1 & Delaware & 73.6 & 59.3 & 8.7 & & Missouri & 55.2 & 32.3 & 22.4 \\
\hline 2 & Virginia & 70.5 & 51.6 & 11.4 & 27 & Ohio & 54.6 & 31.9 & 22.1 \\
\hline 3 & New Hamp & 70.1 & 55.3 & 8.4 & 28 & Kansas & 54.6 & 27.6 & 20.4 \\
\hline 4 & Iowa & 68.4 & 41.5 & 8.3 & 29 & Georgia & 54.5 & 27.6 & 19.3 \\
\hline 5 & Washington & 68.1 & 44.1 & 11.4 & 30 & Wyoming & 54.1 & 24.1 & 18.4 \\
\hline 6 & New Jersey & 67.2 & 42.2 & 13.6 & 31 & Colorado & 53.6 & 30.3 & 21.4 \\
\hline 7 & Vermont & 65.3 & 52.5 & 14.6 & 32 & Hawaii & 51.8 & 16.3 & 21.9 \\
\hline 8 & Florida & 64.4 & 38.7 & 24.2 & 33 & Texas & 51.7 & 27.6 & 25.2 \\
\hline 9 & California & 64.0 & 33.6 & 10.7 & 34 & So Dakota & 50.5 & 23.8 & 33.4 \\
\hline 10 & Connecticut & 63.4 & 40.8 & 13.0 & 36 & No Dakota & 50.3 & 23.3 & 19.8 \\
\hline 11 & Pennsylvania & 62.9 & 41.6 & 8.7 & 35 & Mississippi & 49.8 & 26.4 & 10.9 \\
\hline 12 & Michigan & 62.0 & 34.3 & 17.7 & 37 & Alabama & 49.5 & 25.9 & 19.5 \\
\hline 13 & Illinois & 61.8 & 40.0 & 12.1 & 38 & Kentucky & 48.9 & 24.2 & 21.0 \\
\hline 14 & No Carolina & 61.2 & 37.5 & 12.2 & 39 & Tennessee & 47.9 & 20.8 & 16.9 \\
\hline 15 & Maryland & 60.8 & 39.9 & 27.1 & 40 & Maine & 47.8 & 28.3 & 32.5 \\
\hline 16 & So Carolina & 60.6 & 41.7 & 9.1 & 41 & Utah & 47.1 & 20.6 & 41.5 \\
\hline 17 & Wisconsin & 59.3 & 28.7 & 13.3 & 42 & Oklahoma & 46.2 & 22.8 & 22.3 \\
\hline 18 & New York & 59.2 & 38.7 & 20.2 & 43 & Nevada & 45.8 & 14.9 & 30.4 \\
\hline 19 & Minnesota & 58.6 & 34.2 & 25.1 & 44 & West Virginia & 45.6 & 24.7 & 15.1 \\
\hline 20 & Arizona & 58.4 & 37.2 & 11.5 & 46 & Montana & 45.6 & 20.7 & 20.5 \\
\hline 22 & Massachusetts & 58.3 & 38.2 & 18.3 & 45 & Louisiana & 44.7 & 20.2 & 21.9 \\
\hline 21 & Rhode Island & 58.0 & 34.1 & 16.4 & 47 & New Mexico & 41.7 & 14.4 & 25.8 \\
\hline 23 & Nebraska & 56.2 & 25.7 & 15.0 & 48 & Idaho & 41.4 & 15.7 & 32.5 \\
\hline 24 & Oregon & 55.5 & 30.3 & 24.7 & 49 & Arkansas & 39.7 & 20.6 & 22.9 \\
\hline 25 & Indiana & 55.2 & 32.6 & 27.6 & 50 & Alaska & 30.6 & 10.4 & 55.0 \\
\hline
\end{tabular}

*Source: http://collegecompletion.chronicle.com/state/\#state=in\&sector=public_four 


\section{Appendix B}

Table B1. Numbers of two-year Public Community Colleges by State Distributed in Selected Percentage Ranges of Part-time Students

\begin{tabular}{|c|c|c|c|c|c|c|c|c|c|c|c|c|c|c|c|}
\hline \multirow{2}{*}{\multicolumn{2}{|c|}{$\begin{array}{c}\text { State Public } \\
\text { two-year } \\
\text { Colleges } \\
\text { Ranked by } \\
\text { Graduation } \\
\text { Rate High to } \\
\text { Low }\end{array}$}} & \multirow[b]{2}{*}{$\mathrm{N}$} & \multicolumn{5}{|c|}{$\begin{array}{c}\text { Number of two-year Institutions with } \\
\% \text { Part-time Student Ranges }\end{array}$} & \multirow{2}{*}{\multicolumn{2}{|c|}{$\begin{array}{c}\text { State Public } \\
\text { two-year } \\
\text { Colleges } \\
\text { Ranked by } \\
\text { Graduation } \\
\text { Rate High to } \\
\text { Low }\end{array}$}} & \multirow[b]{2}{*}{$\mathrm{N}$} & \multicolumn{5}{|c|}{$\begin{array}{c}\text { Number of two-year Institutions with } \\
\% \text { Part-time Student Ranges }\end{array}$} \\
\hline & & & $\begin{array}{l}<20 \\
\%\end{array}$ & $\begin{array}{c}20 \%-4 \\
0 \%\end{array}$ & $\begin{array}{c}40 \%-6 \\
0 \%\end{array}$ & $\begin{array}{c}60 \%-8 \\
0 \%\end{array}$ & $\begin{array}{c}>80 \\
\%\end{array}$ & & & & $\begin{array}{l}<20 \\
\%\end{array}$ & $\begin{array}{c}20 \%-4 \\
0 \%\end{array}$ & $\begin{array}{c}40 \%-6 \\
0 \%\end{array}$ & $\begin{array}{c}60 \%-8 \\
0 \%\end{array}$ & $\begin{array}{c}>80 \\
\%\end{array}$ \\
\hline 1 & $\begin{array}{l}\text { So } \\
\text { Dakota }\end{array}$ & 5 & 1 & 4 & - & - & - & $\begin{array}{l}2 \\
6\end{array}$ & Missouri & $\begin{array}{l}1 \\
4\end{array}$ & 1 & 1 & 12 & - & - \\
\hline 2 & $\begin{array}{l}\text { No } \\
\text { Dakota }\end{array}$ & 5 & - & 1 & 3 & 1 & - & $\begin{array}{l}2 \\
7\end{array}$ & Louisiana & $\begin{array}{l}1 \\
6\end{array}$ & - & 2 & 8 & 6 & - \\
\hline 3 & Kansas & 25 & - & 4 & 12 & 9 & - & $\begin{array}{l}2 \\
8\end{array}$ & Idaho & 4 & - & - & 3 & 1 & - \\
\hline 4 & Florida & 5 & - & - & 3 & 2 & - & $\begin{array}{l}2 \\
9\end{array}$ & $\begin{array}{l}\text { No } \\
\text { Carolina }\end{array}$ & $\begin{array}{l}5 \\
9\end{array}$ & - & - & 40 & 18 & 1 \\
\hline 5 & $\begin{array}{l}\text { Wyomi } \\
\text { ng }\end{array}$ & 7 & - & - & 3 & 4 & - & $\begin{array}{l}3 \\
0\end{array}$ & $\begin{array}{l}\text { Oklahom } \\
\text { a }\end{array}$ & $\begin{array}{l}1 \\
2\end{array}$ & - & 3 & 4 & 5 & - \\
\hline 6 & $\begin{array}{l}\text { Wiscon } \\
\sin \end{array}$ & 17 & - & 1 & 7 & 6 & 3 & $\begin{array}{l}3 \\
1\end{array}$ & $\begin{array}{l}\text { New } \\
\text { Jersey }\end{array}$ & $\begin{array}{l}1 \\
9\end{array}$ & - & 2 & 14 & 3 & - \\
\hline 7 & $\begin{array}{l}\text { Washin } \\
\text { gton }\end{array}$ & 25 & - & 8 & 16 & 1 & - & $\begin{array}{l}3 \\
2\end{array}$ & Oregon & $\begin{array}{l}1 \\
6\end{array}$ & - & - & 13 & 3 & - \\
\hline 8 & Alaska & 2 & - & - & - & & 2 & $\begin{array}{l}3 \\
3\end{array}$ & $\begin{array}{l}\text { Massachu } \\
\text { setts }\end{array}$ & $\begin{array}{l}1 \\
6\end{array}$ & - & - & 6 & 10 & - \\
\hline 9 & $\begin{array}{l}\text { Nebrask } \\
\text { a }\end{array}$ & 8 & - & 1 & 4 & 3 & - & $\begin{array}{l}3 \\
4\end{array}$ & Alabama & $\begin{array}{l}2 \\
5\end{array}$ & 1 & 4 & 18 & 2 & - \\
\hline $\begin{array}{l}1 \\
0\end{array}$ & $\begin{array}{l}\text { Californ } \\
\text { ia }\end{array}$ & $\begin{array}{c}11 \\
3\end{array}$ & - & - & 14 & 87 & 12 & $\begin{array}{l}3 \\
5\end{array}$ & Maryland & $\begin{array}{l}1 \\
5\end{array}$ & - & 1 & 1 & 13 & - \\
\hline $\begin{array}{l}1 \\
1\end{array}$ & $\begin{array}{l}\text { Minnes } \\
\text { ota }\end{array}$ & 31 & - & 6 & 15 & 10 & - & $\begin{array}{l}3 \\
6\end{array}$ & Hawaii & 6 & - & - & 1 & 5 & - \\
\hline $\begin{array}{l}1 \\
2\end{array}$ & $\begin{array}{l}\text { Montan } \\
\text { a }\end{array}$ & 10 & 2 & 2 & 6 & - & - & $\begin{array}{l}3 \\
7\end{array}$ & Delaware & 3 & - & - & 2 & 1 & - \\
\hline $\begin{array}{l}1 \\
3\end{array}$ & Iowa & 16 & - & 1 & 10 & 5 & - & $\begin{array}{l}3 \\
8\end{array}$ & $\begin{array}{l}\text { Pennsylv } \\
\text { ania }\end{array}$ & $\begin{array}{l}1 \\
6\end{array}$ & 2 & - & 5 & 9 & - \\
\hline $\begin{array}{l}1 \\
4\end{array}$ & $\begin{array}{l}\text { Mississi } \\
\text { ppi }\end{array}$ & 15 & 4 & 11 & - & - & - & $\begin{array}{l}3 \\
9\end{array}$ & Arizona & $\begin{array}{l}1 \\
9\end{array}$ & - & - & - & 18 & 1 \\
\hline $\begin{array}{l}1 \\
5\end{array}$ & Utah & 1 & - & - & - & 1 & - & $\begin{array}{l}4 \\
0\end{array}$ & Texas & $\begin{array}{l}6 \\
2\end{array}$ & - & 1 & 21 & 35 & 5 \\
\hline $\begin{array}{l}1 \\
6\end{array}$ & $\begin{array}{l}\text { Kentuc } \\
\text { ky }\end{array}$ & 16 & - & - & 9 & 7 & - & $\begin{array}{l}4 \\
1\end{array}$ & $\begin{array}{l}\text { Tennesse } \\
\mathrm{e}\end{array}$ & $\begin{array}{l}1 \\
3\end{array}$ & - & - & 11 & 2 & - \\
\hline $\begin{array}{l}1 \\
7\end{array}$ & Virginia & 24 & - & 1 & 4 & 19 & - & $\begin{array}{l}4 \\
2\end{array}$ & $\begin{array}{l}\text { New } \\
\text { Mexico }\end{array}$ & $\begin{array}{l}1 \\
8\end{array}$ & 1 & - & 4 & 13 & - \\
\hline $\begin{array}{l}1 \\
8\end{array}$ & Maine & 7 & - & 1 & 5 & 1 & - & $\begin{array}{l}4 \\
3\end{array}$ & Michigan & $\begin{array}{l}2 \\
9\end{array}$ & - & - & 9 & 20 & - \\
\hline $\begin{array}{l}1 \\
9\end{array}$ & Illinois & 48 & - & 1 & 22 & 23 & 2 & $\begin{array}{l}4 \\
4\end{array}$ & $\begin{array}{l}\text { Rhode } \\
\text { Island }\end{array}$ & 1 & - & - & - & 1 & - \\
\hline $\begin{array}{l}2 \\
0\end{array}$ & $\begin{array}{l}\text { Arkansa } \\
\text { s }\end{array}$ & 22 & - & 2 & 15 & 5 & - & $\begin{array}{l}4 \\
5\end{array}$ & Ohio & $\begin{array}{l}2 \\
5\end{array}$ & 1 & 1 & 6 & 16 & 1 \\
\hline $\begin{array}{l}2 \\
1\end{array}$ & $\begin{array}{l}\text { New } \\
\text { Hamp }\end{array}$ & 7 & - & - & 2 & 5 & - & $\begin{array}{l}4 \\
6\end{array}$ & $\begin{array}{l}\text { Connectic } \\
\text { ut }\end{array}$ & $\begin{array}{l}1 \\
2\end{array}$ & - & - & 1 & 11 & - \\
\hline $\begin{array}{l}2 \\
2\end{array}$ & Nevada & 1 & - & - & - & 1 & - & $\begin{array}{l}4 \\
7\end{array}$ & $\begin{array}{l}\text { So } \\
\text { Carolina }\end{array}$ & $\begin{array}{l}2 \\
0\end{array}$ & & 1 & 14 & 5 & - \\
\hline $\begin{array}{l}2 \\
3\end{array}$ & $\begin{array}{l}\text { Colorad } \\
\text { o }\end{array}$ & 14 & - & - & 6 & 7 & 1 & $\begin{array}{l}4 \\
8\end{array}$ & $\begin{array}{l}\text { West } \\
\text { Virginia }\end{array}$ & $\begin{array}{l}1 \\
0\end{array}$ & 1 & 5 & 1 & 3 & - \\
\hline $\begin{array}{l}2 \\
4\end{array}$ & $\begin{array}{l}\text { New } \\
\text { York }\end{array}$ & 35 & - & 11 & 24 & - & - & $\begin{array}{l}4 \\
9\end{array}$ & Vermont & 1 & - & - & - & - & 1 \\
\hline $\begin{array}{l}2 \\
5\end{array}$ & Georgia & 28 & 1 & 8 & 19 & - & - & $\begin{array}{l}5 \\
0\end{array}$ & Indiana & 1 & - & - & - & 1 & - \\
\hline
\end{tabular}


Table B2. Numbers of four-year Public Universities by State Distributed in Selected Percentage Ranges of Part-time Students

\begin{tabular}{|c|c|c|c|c|c|c|c|c|c|c|c|c|c|c|c|}
\hline \multirow{2}{*}{\multicolumn{2}{|c|}{$\begin{array}{l}\text { State Public } \\
\text { four-year } \\
\text { Institutions } \\
\text { Ranked by } \\
\text { Graduation Rate } \\
\text { High to Low }\end{array}$}} & \multirow[b]{2}{*}{$\mathrm{N}$} & \multicolumn{5}{|c|}{$\begin{array}{c}\text { Number of four-year Institutions with } \\
\text { \% Part-time Student Ranges }\end{array}$} & \multirow{2}{*}{\multicolumn{2}{|c|}{$\begin{array}{l}\text { State Public } \\
\text { four-year } \\
\text { Institutions } \\
\text { Ranked by } \\
\text { Graduation } \\
\text { Rate High to } \\
\text { Low }\end{array}$}} & \multirow[b]{2}{*}{$\mathrm{N}$} & \multicolumn{5}{|c|}{$\begin{array}{c}\text { Number of four-year Institutions with } \\
\text { \% Part-time Student Ranges }\end{array}$} \\
\hline & & & $<20$ & $\begin{array}{c}20 \%-40 \\
\%\end{array}$ & $\begin{array}{c}40 \%-60 \\
\%\end{array}$ & $\begin{array}{c}60 \%-80 \\
\%\end{array}$ & $\begin{array}{l}>80 \\
\%\end{array}$ & & & & $\begin{array}{l}<20 \\
\%\end{array}$ & $\begin{array}{c}20 \%-40 \\
\%\end{array}$ & $\begin{array}{c}40 \%-60 \\
\%\end{array}$ & $\begin{array}{c}60 \%-80 \\
\%\end{array}$ & $\begin{array}{c}>80 \\
\%\end{array}$ \\
\hline 1 & Delaware & 2 & 2 & - & - & - & - & $\begin{array}{l}2 \\
6\end{array}$ & Missouri & $\begin{array}{l}1 \\
3\end{array}$ & 5 & 7 & 1 & - & - \\
\hline 2 & Virginia & $\begin{array}{l}1 \\
4\end{array}$ & 11 & 3 & - & - & - & $\begin{array}{l}2 \\
7\end{array}$ & Ohio & $\begin{array}{l}1 \\
4\end{array}$ & 9 & 5 & - & - & - \\
\hline 3 & New Hamp & 5 & 3 & 1 & 1 & - & - & $\begin{array}{l}2 \\
8\end{array}$ & Kansas & 7 & 4 & 2 & 1 & - & - \\
\hline 4 & Iowa & 3 & 3 & - & - & - & - & $\begin{array}{l}2 \\
9\end{array}$ & Georgia & $\begin{array}{l}1 \\
7\end{array}$ & 9 & 7 & 1 & - & - \\
\hline 5 & $\begin{array}{l}\text { Washingto } \\
\mathrm{n}\end{array}$ & 8 & 8 & - & - & - & - & $\begin{array}{l}3 \\
0\end{array}$ & $\begin{array}{l}\text { Wyomin } \\
\mathrm{g}\end{array}$ & 1 & 1 & - & - & - & - \\
\hline 6 & New Jersey & $\begin{array}{l}1 \\
2\end{array}$ & 9 & 3 & - & - & - & $\begin{array}{l}3 \\
1\end{array}$ & $\begin{array}{l}\text { Colorad } \\
\text { o }\end{array}$ & $\begin{array}{l}1 \\
1\end{array}$ & 6 & 3 & 2 & - & - \\
\hline 7 & Vermont & 4 & 3 & 1 & - & - & - & $\begin{array}{l}3 \\
2\end{array}$ & Hawaii & 3 & 2 & - & 1 & - & - \\
\hline 8 & Florida & $\begin{array}{l}1 \\
1\end{array}$ & 3 & 8 & - & - & - & $\begin{array}{l}3 \\
3\end{array}$ & Texas & $\begin{array}{l}3 \\
0\end{array}$ & 12 & 15 & 3 & - & - \\
\hline 9 & California & $\begin{array}{l}3 \\
2\end{array}$ & 31 & 1 & - & - & - & $\begin{array}{l}3 \\
4\end{array}$ & $\begin{array}{l}\text { So } \\
\text { Dakota }\end{array}$ & 7 & 1 & 3 & 3 & - & - \\
\hline $\begin{array}{l}1 \\
0\end{array}$ & $\begin{array}{l}\text { Connecticu } \\
\mathrm{t}\end{array}$ & 5 & 4 & 1 & - & - & - & $\begin{array}{l}3 \\
5\end{array}$ & $\begin{array}{l}\text { No } \\
\text { Dakota }\end{array}$ & 7 & 1 & 5 & 1 & - & - \\
\hline $\begin{array}{l}1 \\
1\end{array}$ & $\begin{array}{l}\text { Pennsylvan } \\
\text { ia }\end{array}$ & $\begin{array}{l}3 \\
7\end{array}$ & 32 & 4 & 1 & - & - & $\begin{array}{l}3 \\
6\end{array}$ & $\begin{array}{l}\text { Mississi } \\
\text { ppi }\end{array}$ & 8 & 8 & - & - & - & - \\
\hline $\begin{array}{l}1 \\
2\end{array}$ & Michigan & $\begin{array}{l}1 \\
5\end{array}$ & 9 & 6 & - & - & - & $\begin{array}{l}3 \\
7\end{array}$ & Alabama & $\begin{array}{l}1 \\
3\end{array}$ & 7 & 5 & 1 & - & - \\
\hline $\begin{array}{l}1 \\
3\end{array}$ & Illinois & $\begin{array}{l}1 \\
1\end{array}$ & 8 & 2 & 1 & - & - & $\begin{array}{l}3 \\
8\end{array}$ & $\begin{array}{l}\text { Kentuck } \\
\mathrm{y}\end{array}$ & 8 & 1 & 7 & - & - & - \\
\hline $\begin{array}{l}1 \\
4\end{array}$ & $\begin{array}{l}\text { No } \\
\text { Carolina }\end{array}$ & $\begin{array}{l}1 \\
6\end{array}$ & 14 & 2 & - & - & - & $\begin{array}{l}3 \\
9\end{array}$ & $\begin{array}{l}\text { Tennesse } \\
\mathrm{e}\end{array}$ & 9 & 6 & 3 & - & - & - \\
\hline $\begin{array}{l}1 \\
5\end{array}$ & Maryland & $\begin{array}{l}1 \\
2\end{array}$ & 9 & 1 & 1 & 1 & - & $\begin{array}{l}4 \\
0\end{array}$ & Maine & 7 & 3 & 1 & 3 & - & - \\
\hline $\begin{array}{l}1 \\
6\end{array}$ & $\begin{array}{l}\text { So } \\
\text { Carolina }\end{array}$ & $\begin{array}{l}1 \\
2\end{array}$ & 9 & 3 & - & - & - & $\begin{array}{l}4 \\
1\end{array}$ & Utah & 5 & - & 3 & 2 & - & - \\
\hline $\begin{array}{l}1 \\
7\end{array}$ & Wisconsin & $\begin{array}{l}1 \\
3\end{array}$ & 9 & 4 & - & - & - & $\begin{array}{l}4 \\
2\end{array}$ & $\begin{array}{l}\text { Oklaho } \\
\text { ma }\end{array}$ & $\begin{array}{l}1 \\
2\end{array}$ & 6 & 6 & - & - & - \\
\hline $\begin{array}{l}1 \\
8\end{array}$ & New York & $\begin{array}{l}3 \\
0\end{array}$ & 18 & 10 & 1 & 1 & - & $\begin{array}{l}4 \\
3\end{array}$ & Nevada & 3 & 1 & 1 & - & 1 & - \\
\hline $\begin{array}{l}1 \\
9\end{array}$ & Minnesota & $\begin{array}{l}1 \\
1\end{array}$ & 6 & 2 & 1 & 2 & - & $\begin{array}{l}4 \\
4\end{array}$ & $\begin{array}{l}\text { West } \\
\text { Virginia }\end{array}$ & $\begin{array}{l}1 \\
0\end{array}$ & 7 & 3 & - & - & - \\
\hline $\begin{array}{l}2 \\
0\end{array}$ & Arizona & 3 & 3 & - & - & - & - & $\begin{array}{l}4 \\
5\end{array}$ & Montana & 6 & 3 & 3 & - & - & - \\
\hline $\begin{array}{l}2 \\
1\end{array}$ & $\begin{array}{l}\text { Massachus } \\
\text { etts }\end{array}$ & $\begin{array}{l}1 \\
3\end{array}$ & 8 & 5 & - & - & - & $\begin{array}{l}4 \\
6\end{array}$ & $\begin{array}{l}\text { Louisian } \\
\text { a }\end{array}$ & $\begin{array}{l}1 \\
4\end{array}$ & 5 & 7 & 2 & - & - \\
\hline $\begin{array}{l}2 \\
2\end{array}$ & $\begin{array}{l}\text { Rhode } \\
\text { Island }\end{array}$ & 2 & 1 & 1 & - & - & - & $\begin{array}{l}4 \\
7\end{array}$ & $\begin{array}{l}\text { New } \\
\text { Mexico }\end{array}$ & 6 & 2 & 3 & 1 & - & - \\
\hline $\begin{array}{l}2 \\
3\end{array}$ & Nebraska & 6 & 3 & 2 & 1 & - & - & $\begin{array}{l}4 \\
8\end{array}$ & Idaho & 4 & 1 & 2 & 1 & - & - \\
\hline $\begin{array}{l}2 \\
4\end{array}$ & Oregon & 7 & 2 & 3 & 2 & - & - & $\begin{array}{l}4 \\
9\end{array}$ & $\begin{array}{l}\text { Arkansa } \\
\text { s }\end{array}$ & 9 & 5 & 3 & 1 & - & - \\
\hline $\begin{array}{l}2 \\
5\end{array}$ & Indiana & $\begin{array}{l}1 \\
4\end{array}$ & 5 & 1 & 8 & - & - & $\begin{array}{l}5 \\
0\end{array}$ & Alaska & 3 & - & - & 2 & 1 & - \\
\hline
\end{tabular}




\section{Appendix C}

Table C. Predicted on-time graduation rates for four-year institutions in all 50 states

\begin{tabular}{|c|c|c|c|c|c|c|c|c|c|}
\hline \multirow{2}{*}{$\begin{array}{c}\text { Rank } \\
\mathrm{Y}=\mathrm{A} / \mathrm{x}+\mathrm{B}\end{array}$} & \multirow{2}{*}{ State } & \multirow{2}{*}{ N Schools } & \multicolumn{2}{|c|}{ N \% Part Time } & \multirow{2}{*}{$\begin{array}{c}\mathrm{Y}=\mathrm{A} / \mathrm{X} \\
\mathrm{A}\end{array}$} & \multirow{2}{*}{$\mathrm{R}^{2}$} & \multicolumn{2}{|c|}{$\mathrm{Y}=\mathrm{A} / \mathrm{x}+\mathrm{B}$} & \multirow{2}{*}{$\mathrm{R}^{2}$} \\
\hline & & & $<20 \%$ & $>40 \%$ & & & $\mathrm{~A}$ & B & \\
\hline 1 & Idaho & 4 & 1 & 1 & 398 & 0.99 & 399.7 & -0.1 & 0.99 \\
\hline 2 & Indiana & 14 & 5 & 8 & 257 & 0.98 & 238.2 & 2.5 & 0.99 \\
\hline 3 & Connecticut & 5 & 4 & 0 & 326 & 0.89 & 274.8 & 7.1 & 0.94 \\
\hline 4 & N Hampshire & 5 & 3 & 1 & 255 & 0.71 & 196.7 & 11.5 & 0.90 \\
\hline 5 & Nebraska & 6 & 3 & 1 & 240 & $*$ & 116.7 & 12.7 & 0.84 \\
\hline 6 & Illinois & 11 & 8 & 1 & 273 & 0.75 & 218.0 & 8.1 & 0.83 \\
\hline 7 & Oregon & 7 & 2 & 2 & 443 & 0.53 & 293.3 & 9.7 & 0.83 \\
\hline 8 & Michigan & 15 & 9 & 0 & 278 & 0.77 & 233.7 & 5.9 & 0.82 \\
\hline 9 & Mississippi & 8 & 8 & 0 & 250 & 0.75 & 199.0 & 5.0 & 0.82 \\
\hline 10 & Tennessee & 9 & 6 & 0 & 242 & 0.67 & 183.7 & 5.2 & 0.76 \\
\hline 11 & New York & 30 & 17 & 2 & 157 & $*$ & 120.1 & 8.4 & 0.72 \\
\hline 12 & Georgia & 17 & 9 & 1 & 282 & 0.66 & 276.1 & 0.5 & 0.66 \\
\hline 13 & New Jersey & 12 & 9 & 0 & 301 & 0.26 & 189.3 & 18.1 & 0.63 \\
\hline 14 & Maryland & 12 & 9 & 2 & 274 & 0.54 & 223.2 & 8.0 & 0.59 \\
\hline 15 & Missouri & 13 & 5 & 1 & 357 & 0.46 & 260.2 & 8.5 & 0.58 \\
\hline 16 & Maine & 7 & 3 & 3 & 95 & 0.54 & 50.6 & 21.5 & 0.56 \\
\hline 17 & W Virginia & 10 & 7 & 0 & 234 & 0.51 & 209.2 & 2.0 & 0.51 \\
\hline 18 & Wisconsin & 13 & 9 & 0 & 238 & 0.41 & 170.6 & 7.8 & 0.51 \\
\hline 19 & California & 32 & 31 & 0 & 127 & 0.33 & 110.2 & 5.8 & 0.84 \\
\hline 20 & So Carolina & 12 & 9 & 0 & 310 & 0.47 & 280.3 & 3.7 & 0.48 \\
\hline 21 & Utah & 5 & 0 & 2 & 656 & 0.47 & 577.3 & 2.4 & 0.48 \\
\hline 22 & Colorado & 11 & 6 & 2 & 263 & 0.18 & 159.1 & 11.4 & 0.48 \\
\hline 23 & Ohio & 14 & 9 & 0 & 250 & 0.22 & 163.1 & 13.1 & 0.45 \\
\hline 24 & New Mexico & 6 & 2 & 1 & 270 & $*$ & 75.3 & 24.0 & 0.44 \\
\hline 25 & Oklahoma & 12 & 6 & 0 & 332 & 0.42 & 295.8 & 2.1 & 0.43 \\
\hline 26 & Kansas & 7 & 4 & 1 & 299 & $*$ & 110.3 & 16.0 & 0.42 \\
\hline 27 & No Carolina & 16 & 14 & 0 & 196 & $*$ & 102.3 & 20.7 & 0.39 \\
\hline 28 & Minnesota & 11 & 6 & 3 & 401 & $*$ & 194.0 & 17.6 & 0.36 \\
\hline 29 & Florida & 11 & 3 & 2 & 496 & $*$ & 319.4 & 12.6 & 0.36 \\
\hline 30 & Virginia & 14 & 11 & 0 & 140 & $*$ & 58.8 & 34.9 & 0.35 \\
\hline 31 & Massachusetts & 13 & 8 & 0 & 274 & $*$ & 93.3 & 4.5 & 0.33 \\
\hline 32 & Pennsylvania & 37 & 32 & 1 & 231 & $*$ & 88.0 & 23.7 & 0.32 \\
\hline 33 & Kentucky & 8 & 1 & 0 & 334 & $*$ & 138.1 & 14.3 & 0.32 \\
\hline 34 & Vermont & 4 & 3 & 0 & 423 & 0.29 & 368.4 & 4.9 & 0.29 \\
\hline 35 & Texas & 30 & 11 & 3 & 362 & $*$ & 193.6 & 11.5 & 0.25 \\
\hline 36 & Washington & 8 & 8 & 0 & 415 & $*$ & 185.5 & 22.3 & 0.22 \\
\hline 37 & Montana & 6 & 3 & 0 & 312 & $*$ & 71.8 & 15.6 & 0.11 \\
\hline 38 & Louisiana & 14 & 5 & 2 & 228 & $*$ & 55.3 & 12.7 & 0.05 \\
\hline 39 & Alabama & 13 & 7 & 1 & 217 & $*$ & 59.4 & 14.7 & 0.04 \\
\hline 40 & Arkansas & 9 & 5 & 1 & 216 & $*$ & 25.7 & 14.7 & 0.01 \\
\hline 41 & So Dakota & 7 & 1 & 3 & 495 & $*$ & 53.8 & 17.2 & 0.01 \\
\hline 42 & No Dakota & 7 & 2 & 1 & 431 & $*$ & 28.1 & 22.2 & 0.01 \\
\hline
\end{tabular}

$* \mathrm{R}^{2}$ values were not obtained for $\mathrm{Y}=\mathrm{A} / \mathrm{X}$ model

No model determinations were made for Arizona, Iowa, Hawaii, Nevada, and Alaska (three schools each), Delaware and Rhode Island (two schools each), and Wyoming (one school).

\section{Appendix D}

Table D1. Trendlines for binned graduation rates versus median SAT score for public and private institutions

\begin{tabular}{ccccc}
\hline \multicolumn{2}{c}{ Binned Trendlines of Graduation Rates vs Median SAT for Public and Private Institutions } \\
\hline $\begin{array}{c}\text { Median } \\
\text { SAT }\end{array}$ & $\begin{array}{c}\text { Public } \\
\text { four-year }\end{array}$ & $\begin{array}{c}\text { Private } \\
\text { four-year }\end{array}$ & $\begin{array}{c}\text { Public } \\
\text { six-year }\end{array}$ & $\begin{array}{c}\text { Private } \\
\text { six-year }\end{array}$ \\
\hline 800 & 1.2 & 13.4 & 22.2 & 28.6 \\
900 & 12.2 & 25.0 & 34.0 & 39.1 \\
1000 & 23.2 & 36.7 & 45.8 & 49.6 \\
1100 & 34.2 & 48.3 & 57.6 & 60.1 \\
1200 & 45.2 & 60.0 & 69.4 & 70.6 \\
1300 & 56.2 & 71.6 & 81.2 & 81.1 \\
1400 & 67.2 & 83.3 & 93.0 & 91.6 \\
\hline
\end{tabular}




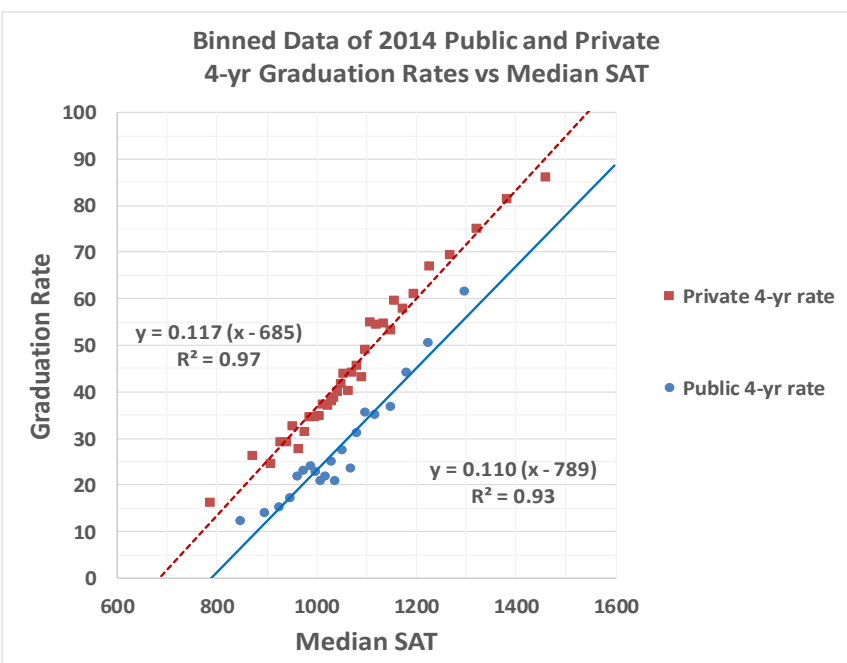

Figure D1a. Trendlines for binned four-year graduation rates versus median SAT score for public and private institutions

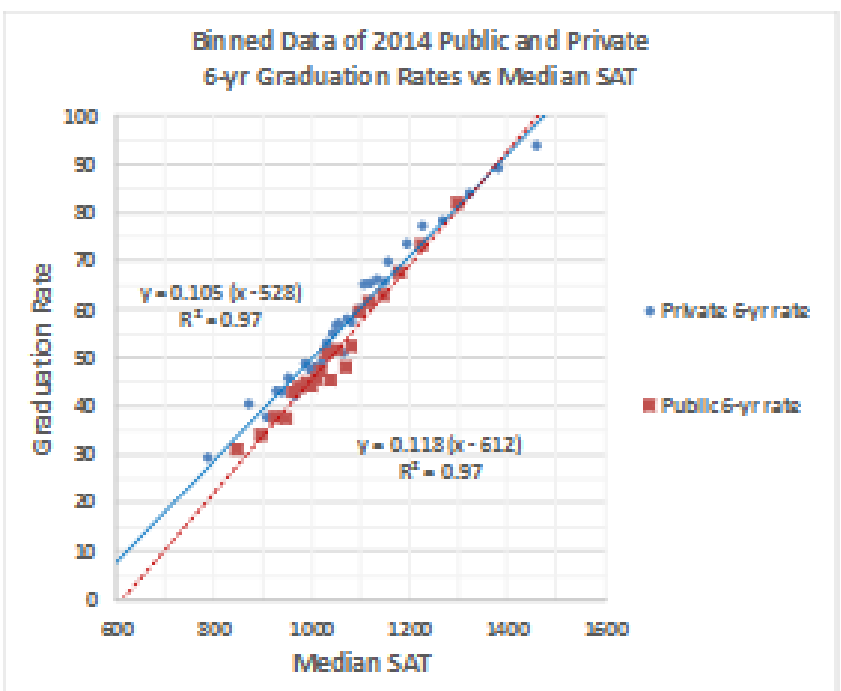

Figure D1b. Trendlines for binned six-year graduation rates versus median SAT score for public and private institutions Table D2. Trendlines for binned graduation rates versus median SAT score for specific states

\begin{tabular}{ccccc}
\hline \multicolumn{5}{c}{ IL, IN, MI, and OH Trend lines of four-year Graduation Rates vs Median SAT } \\
\hline $\begin{array}{c}\text { Median } \\
\text { SAT }\end{array}$ & $\begin{array}{c}\text { OH } \\
\text { four-year }\end{array}$ & $\begin{array}{c}\text { IL } \\
\text { four-year }\end{array}$ & $\begin{array}{c}\text { IN } \\
\text { four-year }\end{array}$ & $\begin{array}{c}\text { MI } \\
\text { four-year }\end{array}$ \\
\hline 800 & - & - & - & - \\
900 & 9.3 & 8.8 & 2.8 & - \\
1000 & 22.1 & 23.4 & 17.7 & 12.8 \\
1100 & 34.9 & 38.0 & 32.6 & 28.6 \\
1200 & 47.7 & 52.6 & 47.5 & 44.4 \\
1300 & 60.5 & 67.2 & 62.4 & 60.2 \\
1400 & 73.3 & 81.8 & 77.3 & 76.0 \\
\hline
\end{tabular}




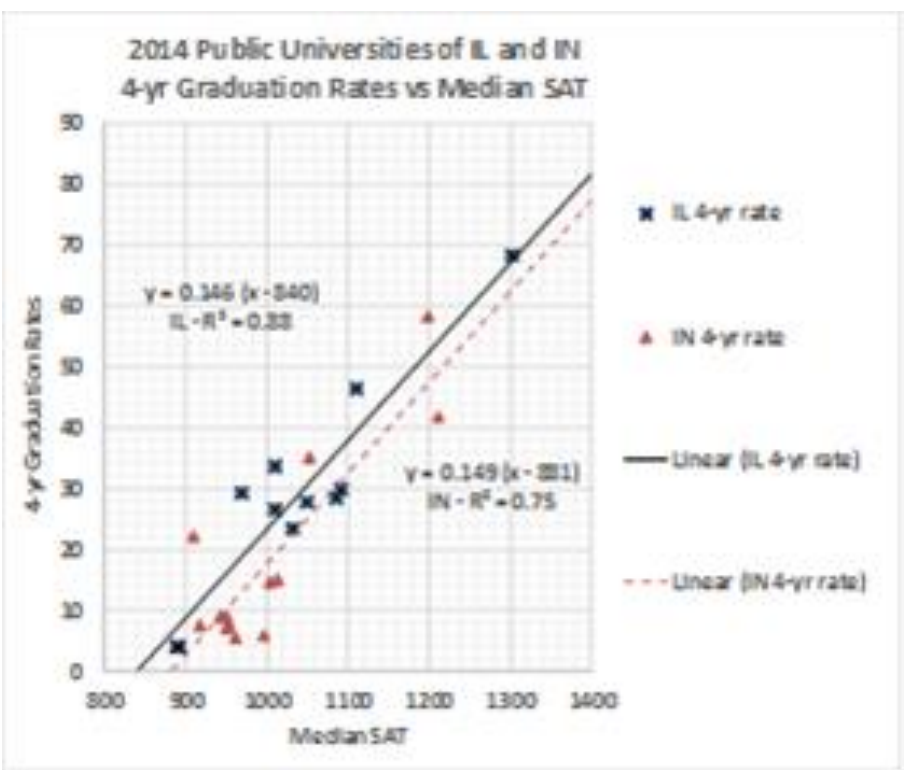

Figure D2a. Trendlines for binned four-year graduation rates versus median SAT score for Illinois and Indiana public and private institutions

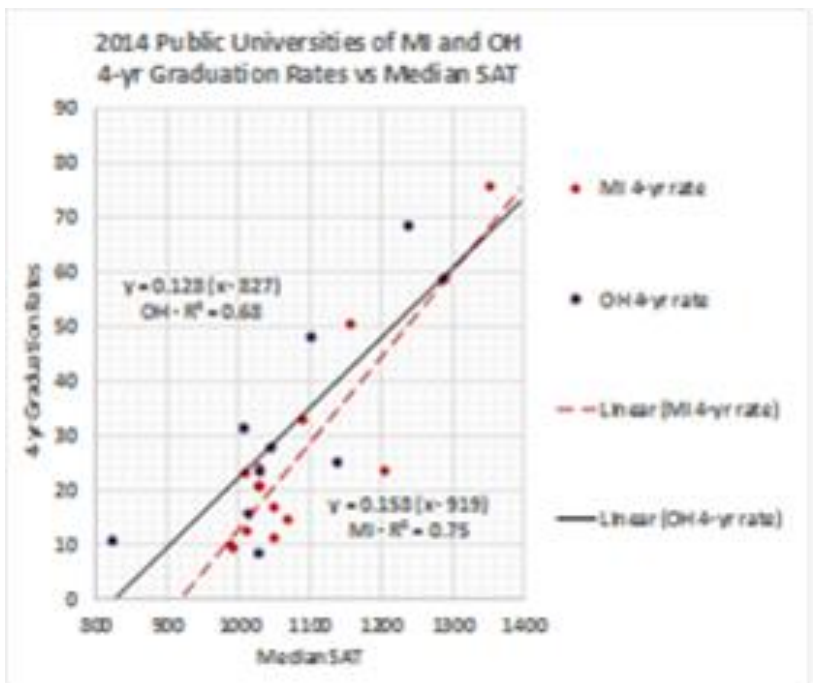

Figure D2b. Trendlines for binned four-year graduation rates versus median SAT score for Michigan and Ohio public and private institutions 


\section{Appendix E}

Table E1. Trajectories for the DeAngelo et al. (2011) HSGPA and SAT data and the three engagement parameters

\begin{tabular}{|c|c|c|c|c|c|c|}
\hline \multicolumn{4}{|c|}{$\begin{array}{c}\text { Maximum Completion Rate } \mathrm{C}_{\max } \text {, Time } \mathrm{t}_{1 / 2} \text { of } 1 / 2 \mathrm{C}_{\max }, \\
\text { and Growth Constant } \alpha \text { for four-, five-, and six-yr Completion } \\
\text { Rates of all Institutions by Type, Race/Ethnicity, } \\
\text { HSGPA, and SAT }\end{array}$} & \multicolumn{3}{|c|}{$\begin{array}{l}\text { ** four-, five-, and six-yr Completion } \\
\text { Rates for 210,056 FTFT Students } \\
\text { Entering fall } 2004 \text { at } 356 \text { four-year } \\
\text { Institutions }\end{array}$} \\
\hline & $\mathrm{C}_{\max }$ & $\mathrm{t}_{1 / 2}$ & $\alpha$ & 4 years & 5 years & 6 years \\
\hline All Institutions & 62.3 & 3.71 & 108.9 & 38.9 & 56.4 & 61.2 \\
\hline College experienced & 65.2 & 3.66 & 116.4 & 42.1 & 59.7 & 64.2 \\
\hline 1st Generation & 51.5 & 3.93 & 91.4 & 27.4 & 44.8 & 50.2 \\
\hline \multicolumn{7}{|l|}{ Ethnicity } \\
\hline African American & 43.0 & 4.03 & 69.5 & 21.0 & 35.6 & 41.3 \\
\hline American Indian & 39.0 & 4.14 & 79.0 & 16.8 & 33.2 & 38.1 \\
\hline Asian/Pacific Islander & 74.8 & 3.76 & 128.5 & 44.9 & 66.8 & 73.2 \\
\hline Latina/o & 53.7 & 4.05 & 85.4 & 25.8 & 44.0 & 51.4 \\
\hline White & 65.1 & 3.66 & 121.7 & 42.6 & 60.2 & 64.3 \\
\hline Multiracial & 57.2 & 3.74 & 100.5 & 34.9 & 51.5 & 56.1 \\
\hline Other & 61.6 & 3.86 & 105.3 & 34.6 & 54.0 & 60.1 \\
\hline \multicolumn{7}{|l|}{ Institution Type } \\
\hline Public University & 66.7 & 3.88 & 129.0 & 37.1 & 59.8 & 65.6 \\
\hline Private University & 78.6 & 3.20 & 145.0 & 64.0 & 75.9 & 78.2 \\
\hline Public four-Year College & 50.9 & 4.08 & 94.9 & 23.5 & 43.1 & 49.5 \\
\hline Nonsectarian four-Year College & 62.4 & 3.25 & 105.0 & 48.7 & 59.3 & 61.8 \\
\hline Catholic four-Year College & 66.4 & 3.18 & 119.4 & 54.1 & 64.0 & 66.0 \\
\hline Other Religious four-Year College & 58.2 & 3.18 & 108.4 & 47.8 & 56.3 & 57.9 \\
\hline \multicolumn{7}{|l|}{ High School GPA } \\
\hline $\mathrm{A}+$ & 80.0 & 3.47 & 148.1 & 58.3 & 75.6 & 79.3 \\
\hline A- & 71.5 & 3.62 & 132.2 & 47.8 & 66.3 & 70.6 \\
\hline $\mathrm{B}+$ & 60.9 & 3.80 & 110.5 & 35.9 & 54.7 & 59.8 \\
\hline $\mathrm{B}$ & 49.8 & 3.99 & 93.1 & 25.2 & 43.3 & 48.7 \\
\hline B- & 38.2 & 4.22 & 67.2 & 15.5 & 30.5 & 36.6 \\
\hline $\mathrm{C}+$ & 28.9 & 4.35 & 55.0 & 9.8 & 22.4 & 27.7 \\
\hline $\mathrm{C}$ & 22.6 & 4.52 & 41.5 & 6.3 & 16.0 & 21.2 \\
\hline \multicolumn{7}{|l|}{ SAT Composite Score } \\
\hline $1300+$ & 82.3 & 3.38 & 149.8 & 62.2 & 78.2 & 81.6 \\
\hline $1200-1299$ & 74.0 & 3.55 & 139.0 & 51.9 & 69.5 & 73.3 \\
\hline $1100-1199$ & 66.5 & 3.68 & 123.0 & 42.9 & 61.2 & 65.6 \\
\hline $1000-1099$ & 59.6 & 3.82 & 111.5 & 34.8 & 53.7 & 58.6 \\
\hline $900-999$ & 51.1 & 4.04 & 97.0 & 24.6 & 44.0 & 49.9 \\
\hline $800-899$ & 42.0 & 4.20 & 76.8 & 17.2 & 34.1 & 40.5 \\
\hline Less than 800 & 32.2 & 4.41 & 57.5 & 10.5 & 23.9 & 30.4 \\
\hline
\end{tabular}

**Source: http://heri.ucla.edu/DARCU/CompletingCollege2011.pdf

\section{Appendix F}

\section{Logistic Curves}

The logistic curve for a population $\mathrm{P}(\mathrm{t})$ at time $\mathrm{t} \geq 0$ can be expressed as

$$
\begin{gathered}
\mathrm{P}(\mathrm{t})=\left[\mathrm{A}+\mathrm{B} \mathrm{e}^{-\mathrm{at}}\right]^{-1} \\
\mathrm{P}(\mathrm{t})=(1 / \mathrm{A}) /\left[1+(\mathrm{B} / \mathrm{A}) \mathrm{e}^{-\mathrm{at}}\right]
\end{gathered}
$$

If classes of size $p_{1}, p_{2}$, and $p_{3}$ are available at equidistant times $t_{1}, t_{2}$, and $t_{3}$ and $t_{3}=\left(2 t_{2}-t_{1}\right)$ with $p_{1}<p_{2}<p_{3}$, then the population ceiling " $a$ " is given by

$$
a=\left[\frac{1}{p_{1}}+\frac{1}{p_{3}}-\frac{2}{p_{3}}\right] \div\left[\frac{1}{p_{1} p_{3}}-\frac{1}{p_{2}^{2}}\right]
$$

Here "a' could be the upper limit on the class achieving passage of some test. Chapter 5, Problem 4 of Beekman (1984) contains the proof of this result. That reference contains many other results for the logistic curve. This analysis uses a logistic model for SAT scores and family variables to predict probabilities of graduation rates at four years, five years, and six years. In addition, the analysis includes a logistic growth model and three years of empirical trajectory data for an institution's bachelor's degree graduation rates to obtain three parameters-a graduation rate growth measure, a maximum completion rate, and a time to reach one-half the maximum achievable graduation rate.

\section{Copyrights}

Copyright for this article is retained by the author(s), with first publication rights granted to the journal.

This is an open-access article distributed under the terms and conditions of the Creative Commons Attribution license which permits unrestricted use, distribution, and reproduction in any medium, provided the original work is properly cited. 